\title{
Role of Hedgehog Signaling in Vasculature Development, Differentiation, and Maintenance
}

\author{
Candice Chapouly, Sarah Guimbal, Pierre-Louis Hollier and Marie-Ange Renault * \\ Biology of Cardiovascular Diseases, Universite Bordeaux, U1034, CHU de Bordeaux, F-33604 Pessac, France; \\ candice.chapouly@inserm.fr (C.C.); sarah.guimbal@gmail.com (S.G.); p-1_hollier@hotmail.fr (P.-L.H.) \\ * Correspondence: marie-ange.renault@inserm.fr; Tel.: +33-5-5789-1979; Fax: +33-5-5636-8979
}

Received: 3 June 2019; Accepted: 20 June 2019; Published: 24 June 2019

\begin{abstract}
The role of Hedgehog (Hh) signaling in vascular biology has first been highlighted in embryos by Pepicelli et al. in 1998 and Rowitch et al. in 1999. Since then, the proangiogenic role of the Hh ligands has been confirmed in adults, especially under pathologic conditions. More recently, the Hh signaling has been proposed to improve vascular integrity especially at the blood-brain barrier (BBB). However, molecular and cellular mechanisms underlying the role of the Hh signaling in vascular biology remain poorly understood and conflicting results have been reported. As a matter of fact, in several settings, it is currently not clear whether Hh ligands promote vessel integrity and quiescence or destabilize vessels to promote angiogenesis. The present review relates the current knowledge regarding the role of the Hh signaling in vasculature development, maturation and maintenance, discusses the underlying proposed mechanisms and highlights controversial data which may serve as a guideline for future research. Most importantly, fully understanding such mechanisms is critical for the development of safe and efficient therapies to target the Hh signaling in both cancer and cardiovascular/cerebrovascular diseases.
\end{abstract}

Keywords: Hedgehog; vasculogenesis; angiogenesis; endothelium; blood-brain barrier

\section{Introduction}

The Hedgehog (Hh) family of morphogens, which includes Sonic Hedgehog (Shh), Indian hedgehog (Ihh), and Desert Hedgehog (Dhh), was identified nearly four decades ago in Drosophila as critical regulators of cell fate determination during embryogenesis [1].

Shh is the most widely expressed and studied. It has been implicated in the development of multiple organs including the central nervous system (CNS), lungs, foregut, heart, and limbs [2] by participating in axis orientation and orchestrating branching morphogenesis. The role of Ihh and Dhh is restricted to a limited number of organs. While Ihh participates in the development of the gut, bones, and kidneys [3,4], Dhh orchestrates the development of testis and peripheral nerves $[5,6]$. In adults, the Hh signaling is generally silent, but participates in tissue maintenance and regeneration by controlling stem cell renewal and differentiation in the brain subventricular zone and in hair follicles [7]. Besides, inappropriate activation of Hh signaling has been linked to several disparate human cancers including basal cell carcinoma, medulloblastoma, lung cancer, and pancreatic adenocarcinoma [8].

The role of the Hh signaling in vascular biology has first been highlighted in embryos by Pepicelli et al. in 1998 [9] and Rowitch et al. in 1999 [10]. Indeed, while the first study reveals a sparser lung vascular network in Shh deficient embryo, the second study shows that ectopic Shh expression induces hypervascularization suggesting a proangiogenic role of the Hh signaling. Since then, the proangiogenic role of Hh ligands has been confirmed in adults especially in pathologic conditions [11-13]. Moreover, Hh ligands have been shown to regulate blood vessel maturation [14], integrity [15], and arterial differentiation [16]. As a consequence, the therapeutic potential of Hh signaling agonists for vascular 
diseases is of growing interest [17-22]. However, molecular and cellular mechanisms underlying the role of the Hh signaling in vascular biology remain poorly understood. The present review summarizes the current knowledge and discrepancies regarding the role of Hh signaling in vasculature development, differentiation, and maintenance, which is important to consider for future research directions and therapeutic perspectives.

\section{Hedgehog Signaling and Regulation}

\subsection{Regulation of Hh Ligand Secretion}

Shh is synthetized as a preprotein of which the signal sequence is first cleaved to produce a full-length unmodified form. An autocatalytic reaction removes then the carboxy-terminal domain and attaches a cholesterol moiety to the newly exposed carboxy-terminus. Shh is further modified by Hedgehog acyltransferase (Hhat), which catalyzes the addition of a palmitate to the amino-terminus [23] (Figure 1). Ihh and Dhh processing have been poorly investigated, and may differ. As a matter of fact, Dhh is suggested not to undergo efficient autocatalytic cleavage [24].

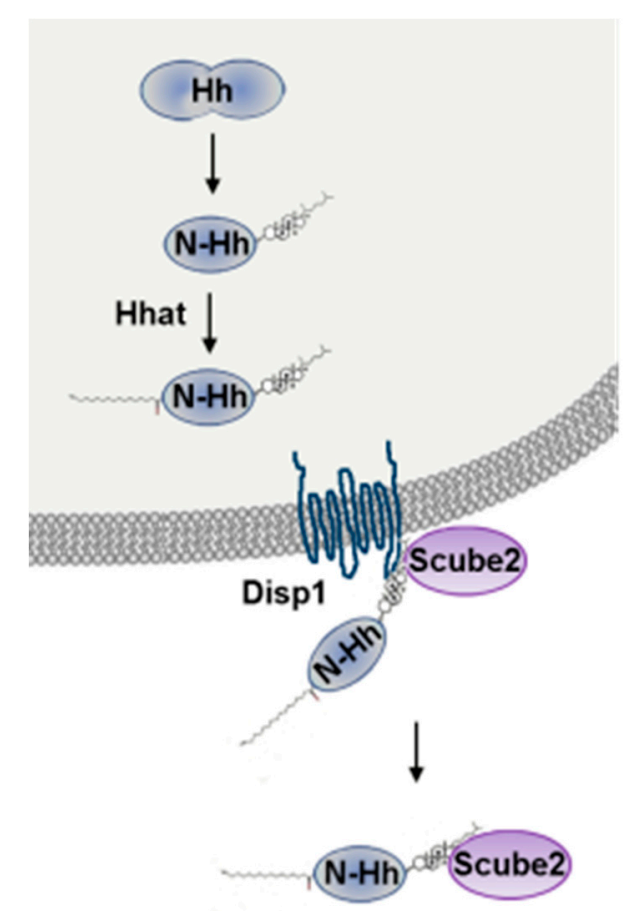

Figure 1. Shh post-transcriptional modification and secretion. Shh is synthetized as a full-length, $45 \mathrm{kDa}$ protein. An autocatalytic reaction removes the carboxy-terminal domain and attaches a cholesterol moiety to the newly exposed carboxy-terminus. Then, Hhat catalyzes the addition of a palmitate to the amino-terminus [23]. Secretion and solubility of Shh depends on Disp1 and Scube2.

Secretion and solubility of cholesterol-modified Hh ligands depend on the transmembrane protein Disp1 (dispatched RND transporter family member 1) and the cell surface protein Scube2 (signal peptide, CUB domain and EGF-like domain containing 2) (Figure 1) [25]. Both Disp1 and Scube2 bind the cholesterol-anchor of Shh.

\subsection{Hh Signaling}

The interaction of the Hh proteins with their specific receptor Patched-1 (Ptch1) de-represses the transmembrane protein Smoothened (Smo), which activates downstream pathways, including the Hh canonical pathway leading to the activation of Gli transcription factors and so-called Hh noncanonical pathways, which are independent of Smo and/or Gli (Figure 2) [26]. 


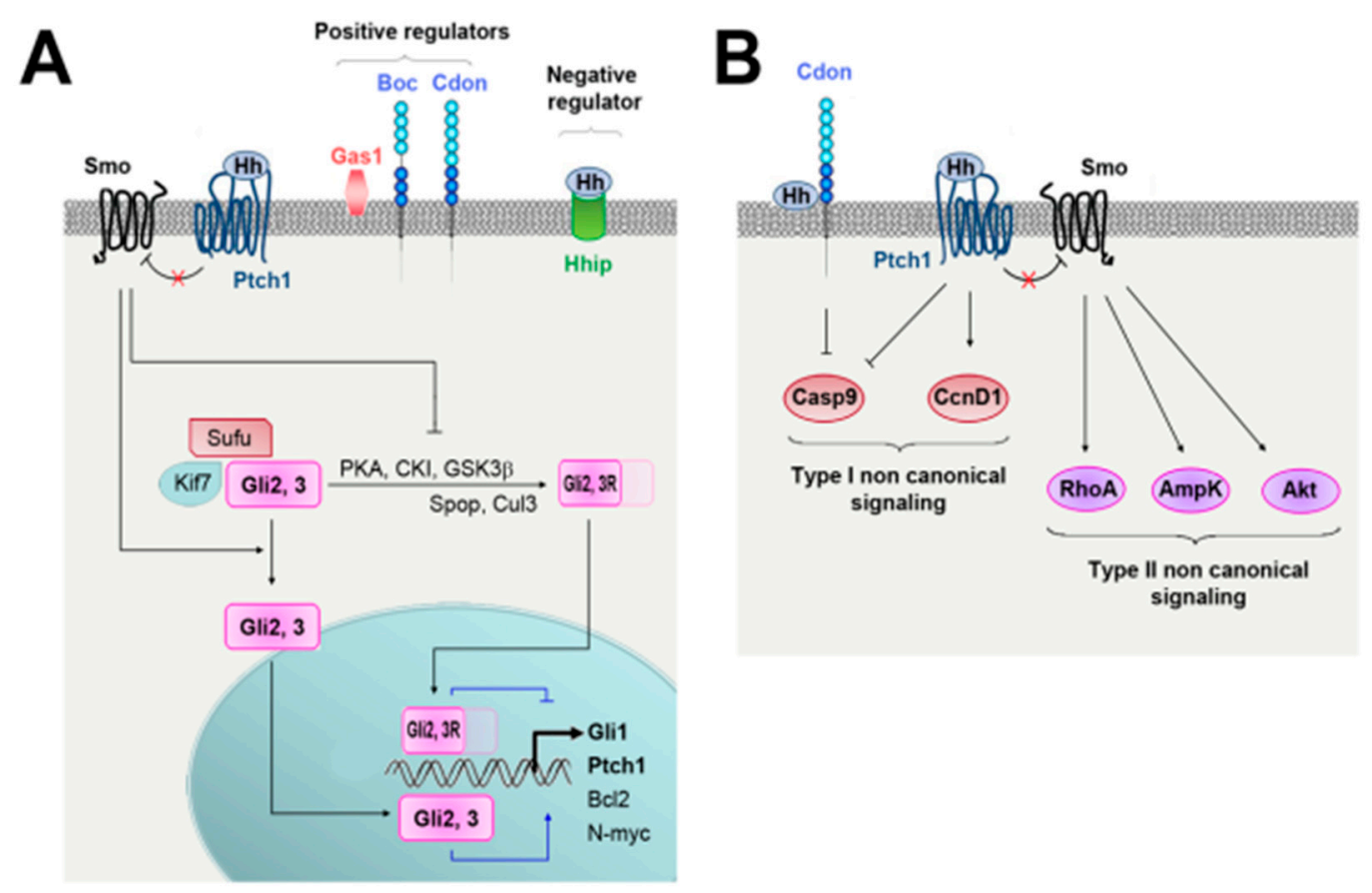

Figure 2. (A) Hh canonical signaling. In the absence of Hh ligands, Smo is inhibited by Ptch1 and Gli transcription factors are associated with SUFU negative regulator of hedgehog signaling (Sufu) and kinesin family member 7 (Kif7). This last complex promotes Gli3 and Gli2 phosphorylation by cAMP dependent protein kinase (PKA), casein kinase 1 (CK1), and glycogen synthase kinase 3 beta (GSK3. Once phosphorylated, Gli2 and Gli3 are processed by speckle type BTB/POZ protein (Spop)/cullin 3 (Cul3) ubiquitin ligase complex to generate Gli2R and Gli3R (repressor forms) respectively. Hh ligands binding to Ptch1 leads to Smo activation, which prevents Gli2 and Gli3 cleavage. Full-length Gli2 and Gli3 may then translocate to the nucleus and activates transcription. (B) Hh noncanonical signaling. Hh binding to Ptch1 or Cdon may, independently on Smo, promote cell survival or proliferation by modulating Caspase 9 (Casp9) or Cyclin D1 (CcnD1) activity, respectively. This is what is called type I noncanonical signaling. Alternatively, Hh ligands may activate PI3K/Akt, RhoA/ROCK or AMPK, via Smo, but independently on Gli transcription factors. This is what is called type II noncanonical signaling.

Activation of the Hh canonical pathway promotes cell survival and proliferation through the regulation of Bcl2, N-myc and CyclinD1 while the noncanonical signaling has been involved in cytoskeleton changes and cell migration [26]. Hh-induced paracrine signaling on adjacent cells is the most common mode of pathway transduction, although Hh has also been proposed to signal in an autocrine manner.

\subsection{Regulation of Hh Signaling}

Hh binding to Ptch1 is regulated by several coreceptors. Among these, Cell adhesion molecule-related/ downregulated by oncogenes (Cdon), Brother of Cdon (Boc) and Growth arrest specific 1 (Gas1) are suggested to promote Hh ligand interaction with Ptch1 while Hedgehog interacting protein (Hhip) inhibits it [27] (Figure 2A).

Beside, Hh signaling activity has been shown to depend on the primary cilium. Indeed, several Hh signaling pathways elements including Smo, Sufu, Kif7, Gli2, and Gli3 have been located at the primary cilium and disruption of genes encoding for cilia proteins such as intraflagellar transport proteins (Ift), talpid3, and Dzip1/Iguana recapitulates most features of Shh deficiency [28]. 


\section{Vascular Development}

\subsection{Yolk Sac Vascularization}

Hh signaling has been shown to orchestrate angiogenesis in the yolk sac as Smo $\mathrm{KO}^{\text {embryos fail }}$ to form yolk sac blood vessels [29]. Ihh, secreted from the primitive endoderm, seems to be the main ligand responsible for this effect [30]. Nevertheless, while Smo ${ }^{\mathrm{KO}}$ embryos do not form any blood vessels, Ihh $\mathrm{KO}$ embryos do form ones which fail to undergo vascular remodeling, i.e., ramification into large and small branches and pericyte coverage [29,31]. This suggests that either Shh and/or Dhh also participate in yolk sac vascularization or that Ihh effects are partly compensated by Shh and/or Dhh in the absence of Thh. Hh signaling has been shown to promote vasculogenesis through forkhead box F1 (FoxF1) and bone morphogenetic protein 4 (BMP4) [30,32], while vessel remodeling seems to depend on (vascular endothelial growth factor) VEGF, kinase insert domain receptor (KDR/Flk-1), and notch receptor 1 (Notch-1) [31] (Figure 3).

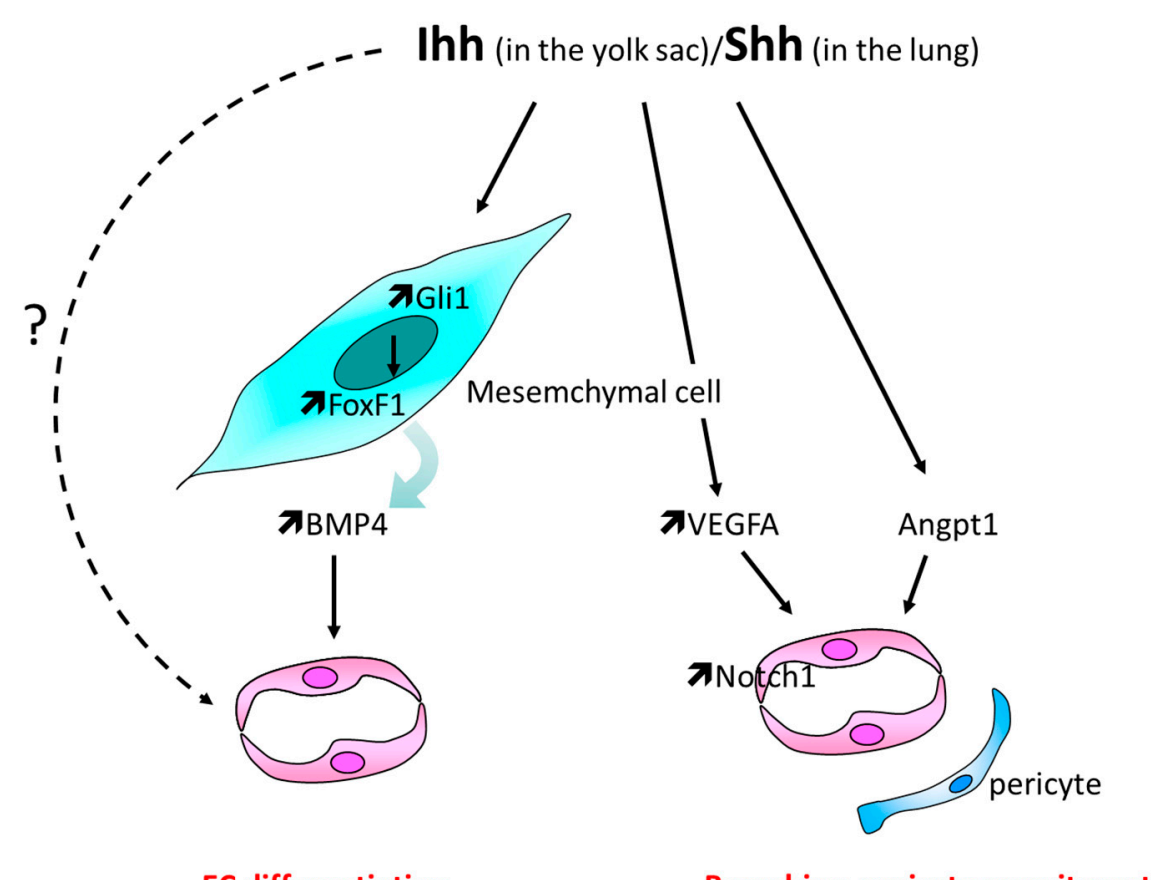

EC differentiation

Branching, pericyte recruitment

Figure 3. Schema representing the main cellular events involved in Hh-induced vasculogenesis and primary vascular plexus remodeling. Hh ligands promote EC differentiation indirectly via BMP4 upregulation in mesenchymal cells, while vascular remodeling, i.e., branching and pericyte recruitment, depends on Vegfa and/or Angpt1.

At the cellular level, it is still not clear which cell types respond to Ihh signals: in vitro, endothelial cells (EC) themselves are suggested to respond to Ihh since C166 cells, a mouse yolk sac EC line, respond to Shh recombinant protein by overexpressing Gli1 and Ptch1 and migrating more. In these cells, Shh also increases expression of neuropilin 1 (Nrp1), Kruppel like factor 4 (Klf4), jagged canonical Notch ligand 1 (Jag1), and collagen type IV alpha 1 chain (Col4a1), major factors implicated in EC biology [33].

\subsection{Lungs Vasculature Development}

Shh-deficient mouse lungs have first been reported as poorly vascularized by Pepicelli et al. in 1998 [9]. Later on, altered vasculature characterized by a sparse network with large gaps between capillaries has been outlined in both $\mathrm{Shh}^{\mathrm{KO}}$ and $\mathrm{Smo}^{\mathrm{KO}}$ mouse embryos especially in the distal part of the lungs $[34,35]$. Notably, Vegfa expression depends on Smo in the distal part of the lung while its 
expression in the subepithelial mesenchyme appears to be less dependent on the Hh signaling [35]. However, according to Van Tuyl et al., the pulmonary vascular bed is decreased in Shh ${ }^{\mathrm{KO}}$ embryos, but appropriate to the decrease in airway branching. In the same study, Vegfa expression is reportedly not different from that of control lung [36] and early vascular development in lungs, mediated by Vegf/Kdr signaling is then suggested to proceed normally in Shh ${ }^{\mathrm{KO}}$ embryos likely because of possible compensatory effects from the other Hh ligands. On the contrary, vascular stabilization is defective because of angiopoietin 1 (Angpt1) downregulation [36].

At the cellular level, the lung capillary network development does not depend on a direct effect of Shh on EC since it is normal in Smo ${ }^{\mathrm{ECKO}}$ lungs [35]. In contrast, it depends on Shh-induced FoxF1 expression, via Gli-binding sites in unidentified cells, most likely of mesenchymal type [37] (Figure 3).

\subsection{Formation of the Aorta and Intersomitic Vessels}

Hh signaling is also necessary for the formation of the aorta. In avian embryos, Smo and Shh inhibition using cyclopamine and 5E1 blocking antibodies, respectively, are reported to impair both aorta formation and remodeling [38-40] and activation of the Hh pathway with SAG leads to the formation of an enlarged aorta. It has also been highlighted that angioblasts of $\mathrm{Smo}^{\mathrm{KO}}$ mouse embryos fail to organize and form the aorta especially in the anterior two-thirds of the embryo [38] while over activation of the Hh pathway through deletion of Ptch1-a negative regulator of Hh signaling results in a dilated dorsal aorta [41]. Consistently, studies performed in zebrafish embryos report that Sonic-you (Syu) (Shh ortholog), You-too (yot) (Gli2 ortholog), Smo mutant, or cyclopamine-treated zebrafishes fail to form the dorsal aorta $[16,42,43]$ and that administration of 5E1 Hh-blocking antibodies result in many vascular defects including delayed fusion of the dorsal aorta and hemorrhage [39]. Besides, Shh promotes arterial differentiation, since Syu, yot, and Smo mutant zebrafishes fail to express EphrinB2, an arterial-specific marker [16] (Figure 4).

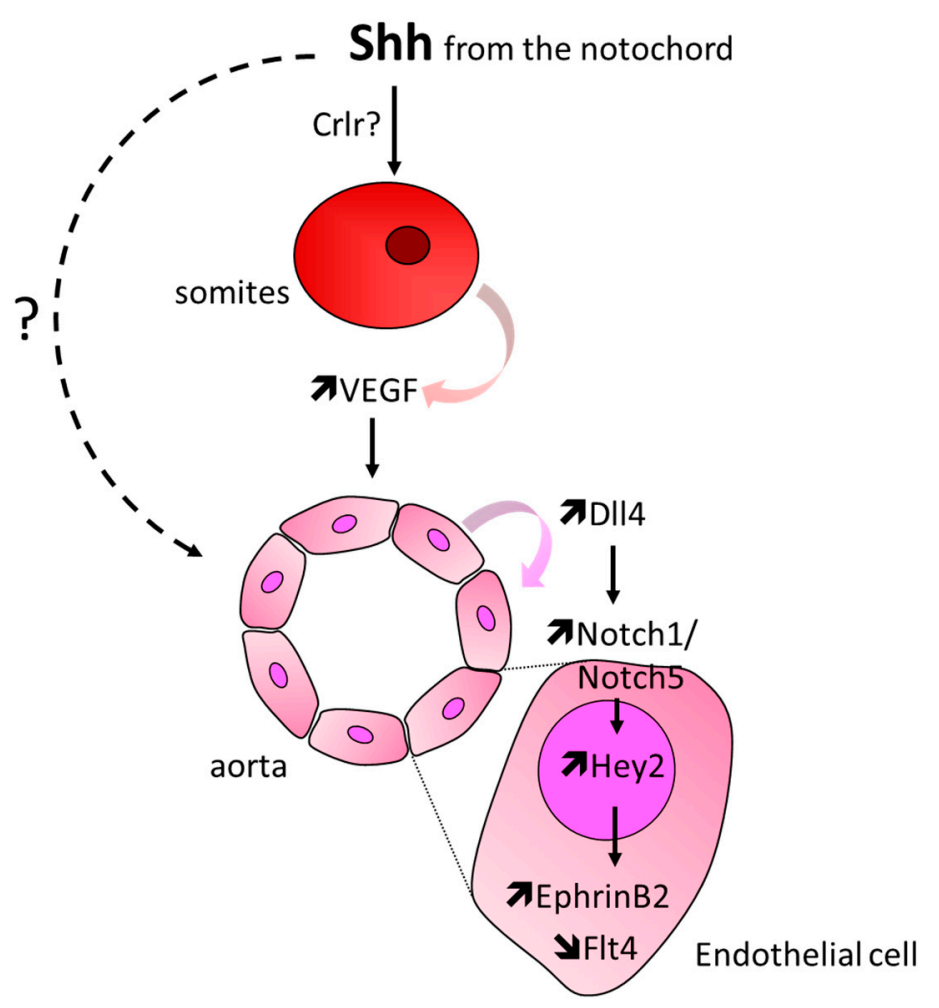

Figure 4. Schema representing the main cellular events involved in Hh-induced arterial differentiation. Briefly, Shh produced by the notochord upregulates Vegfa in somites, which, in turn, increases Notch signaling in ECs, and subsequently promotes the expression of the arterial marker EphrinB2. 
Shh is proposed to promote tube formation and arterial identity via Vegfa [16,41,44]; more specifically, Shh may induce Vegfa expression in somites via calcitonin receptor-like receptor (crlr) [45] which in turn promotes Notch 5 expression in ECs. Activation of Noth signaling, subsequently, inhibits Flt4 and promotes EphrinB2 expression [16]. As an alternative, Shh is suggested to be necessary for angioblasts to organize and to promote arterial identity by repressing venous cell fate in angioblasts [43]. This is supported by the fact that angioblasts and later on, aortic ECs express Ptch1, Ptch2, and Smo [38].

Artery and vein identity was reported to be established normally in igu ${ }^{f o 10 a}$ mutants (The zebrafish genetic mutant iguana (igu) has defects in the ciliary basal body protein Dzip1, causing improper cilia formation and disruption of Hh signaling [46].

\subsection{Involvement of Hh Signaling in the Setting of Other Vascular Bed Development}

Hh signaling is involved in the vascular development of other organs notably the retina, brain, skeleton, and heart.

The retina: Hh signaling is implicated in retinal angiogenesis, as cyclopamine inhibits retinal angiogenesis [47], and is shown to be necessary for both retinal EC and pericyte survival. Indeed, Shh promotes Ptch1, Gli2, Notch1, Notch3, Bcl2, and Bclxl, but inhibits Bax expression in retinal ECs, while it promotes Ptch1, Gli2, Notch1, and Bcl3 in pericytes. However, while pulsatile flow promotes Hh signaling and retinal EC survival, it inhibits it in retinal pericytes [48].

The brain: Gli2 deficient embryos have been reported to lack the entire brain basilar artery [49] and Shh, produced by the hindbrain choroid plexus epithelial cells, to promote hind brain vascularization. Shh more likely signals to pericytes but not ECs to, since only pericytes are reported to express Ptch1 in this study [50].

The skeleton: Ihh promotes skeletal blood vessel 3D organization and stability [51] and Shh recombinant protein enhances angiogenesis and osteogenesis in a co-culture system consisting of primary osteoblasts and outgrowth ECs [52]. In bones, Ihh is proposed to act downstream of the Vegf signaling since the Vegfa/Vegfr2 signaling stimulates its expression and activity [53].

The heart: Shh is necessary for FGF9-induced Vegfa, Vegfb, Vegfc, and Angpt2 expression in cardiomyocytes and perivascular cells [54] and the Hh signaling to cardiomyocytes is required for the development of coronary veins, while Hh signaling to perivascular cells seems necessary for coronary arterial growth [55].

Somite: In avian embryos, inhibition of Smo and Shh compromise intersomitic vessel growth [56], while activation of the Hh pathway with SAG leads to a densified plexus. Moreover, the number of EC filopodia is found to correlate with Hh signaling activity since the number of filopodia decreases in cyclopamine-treated embryos, while increases in the SAG-treated embryos [40]. At a molecular level, growth of intersomitic vessels seems to be dependent on Vegfa, but independent on Notch or BMP [56].

Finally, ectopic Shh overexpression in the dorsal neural tube was shown to induce spinal cord hypervascularization [10], while ectopic expression of a constitutively active form of Smo (SmoM2) in the ovaries was shown to increase the density of CD31+ endothelial tubes in newborn mice [57].

\subsection{Controversial Data}

Even though Hh signaling appears to promote vascular development in the yolk sac, lungs, bones, heart, retina, and ovaries, organ specificity exists and contradicting observations have been made: for example, superficial vessel development in the zebrafish eye is increased due to excessive vessel sprouting in Smo deficient fish [58], while, in accordance with previous reports, vegf showed a clear downregulation. It has also been described that Talpid3 (a gene necessary for the Hh signaling that participates in primary cilium formation)-deficient chicken embryos display severe vascular defects including enlarged and more numerous blood vessels. Moreover, electron-dense junctions between talpid3 ECs appeared less well-defined which is associated with hemorrhage and edema [59]. The expression of Vegfa is unchanged, while Vegfd, Rigf (retinoic-acid induced growth factor, a chicken member of Vegf family), and angiopoietin 2a (Angpt2a) are overexpressed. Nrp1 is expressed by both 
veins and arteries and Nrp2, normally expressed in veins, is absent. Moreover, this study reported that ectopic expression of Shh leads to a decreased capillary density, a transient upregulation of Nrp1 and Angpt2 but no modulation of neuropillin 2 (Nrp2) [59].

\section{Postnatal Angiogenesis}

In addition to its role in embryo vascularization, the Hh signaling has also been identified as regulating postnatal angiogenesis, especially in the setting of ischemia [11] and cancer [60].

\subsection{In the Setting of Ischemia}

\subsubsection{Role of Hh-Signaling in Ischemia-Induced Angiogenesis in the Hindlimb}

The Hh signaling has been shown to be reactivated in ischemic conditions especially in the hindlimb muscle. Shh [61,62], Gli1 [63,64], Gli2, and Gli3 [65] were shown to be strongly upregulated in the ischemic muscle compared to the contralateral nonischemic muscle. Reactivation of $\mathrm{Hh}$ signaling is suggested to promote revascularization of ischemic tissues since systemic administration of Hh-blocking antibodies (5E1) decreases capillary density and reperfusion of the ischemic limb [61]. Besides, overactivation of Hh signaling by ectopic administration of a Shh-expressing vector [66], Shh-carrying microparticles [67], or the Smo-agonist SAG [68] increases capillary density in the ischemic muscle.

Reactivation of Hh signaling is suggested to be impaired in the setting of aging since Gli1 expression in the ischemic muscle is diminished in aged mice [63,64]. Dhh and Smo, but not Shh expression, were shown to be downregulated in aged mice [64]. Because of the proangiogenic properties of Hh ligands, impaired activation of Hh signaling in aged mice is proposed to compromise ischemia-induced angiogenesis. This paradigm is supported by the fact that administration of $\mathrm{Hh}$ ligands either systemically [11] or locally [63,64] increases capillary density, promotes ischemic muscle perfusion, and limb salvage in aged mice.

\section{Controversial Data}

It still remains unclear which Hh ligand(s) regulate ischemia-induced angiogenesis. Indeed, angiogenesis has been shown to be transiently accelerated in Shh iKO mice [66] suggesting that endogenous Shh has antiangiogenic properties rather than proangiogenic ones. Besides, we found that angiogenesis is impaired in Dhh constitutive KO mice [62] but this is more likely the result of an impaired peripheral nerve development since the same phenotype is recapitulated in denervated mice but not in mice in which Dhh KO is induced in adult mice (unpublished data). Therefore, according to the results obtained so far, neither Shh nor Dhh seem to be promoting angiogenesis in the setting of hindlimb ischemia. Another option is that Hh signaling may be activated through noncanonical signaling, regardless of any Hh ligands. For example, Gli3, which is necessary for ischemia-induced angiogenesis [65], is upregulated by E2F1 in myoblasts [69].

The Hh signaling to ECs does not participates in ischemia-induced angiogenesis since angiogenesis occurs normally in Smo ${ }^{\mathrm{ECKO}}$ mice [62,70]. On the contrary, Hh ligands are proposed to promote angiogenesis indirectly by increasing proangiogenic factor expression (Vegfa, Angpt1, Angpt2) in fibroblasts $[11,63]$. Hh ligands were also shown to promote recruitment of bone marrow derived proangiogenic cells in ischemic tissues [63] (Figure 5) and Hh signaling may promote angiogenesis by regulating myogenesis. Indeed, $\mathrm{Gli}^{\mathrm{ECKO}}$ does not alter ischemia-induced angiogenesis, while angiogenesis is impaired in mice in which Gli3 expression is disrupted in myoblasts [69]. Moreover, Gli3 regulates Angpt1 and thymidine phosphorylase (TYMP) expression in myoblasts. Finally, Shh has been shown promotes myogenesis in adults in both cardiotoxin and mechanical crush-induced muscle injury models [71,72]. Shh, when administered ectopically, does not recapitulate endogenous Shh effects [66], suggesting that ectopic Hh ligand and endogenous Hh ligand control ischemia-induced angiogenesis through distinct mechanisms, e.g. ectopically administered Shh increases Vegfa expression 
in fibroblasts, while endogenous Shh decreases C-C motif chemokine ligand 2 (Ccl2) expression in myoblasts which results in a decreased macrophage invasion and diminished macrophage-derived Vegfa levels in the ischemic muscle [66].

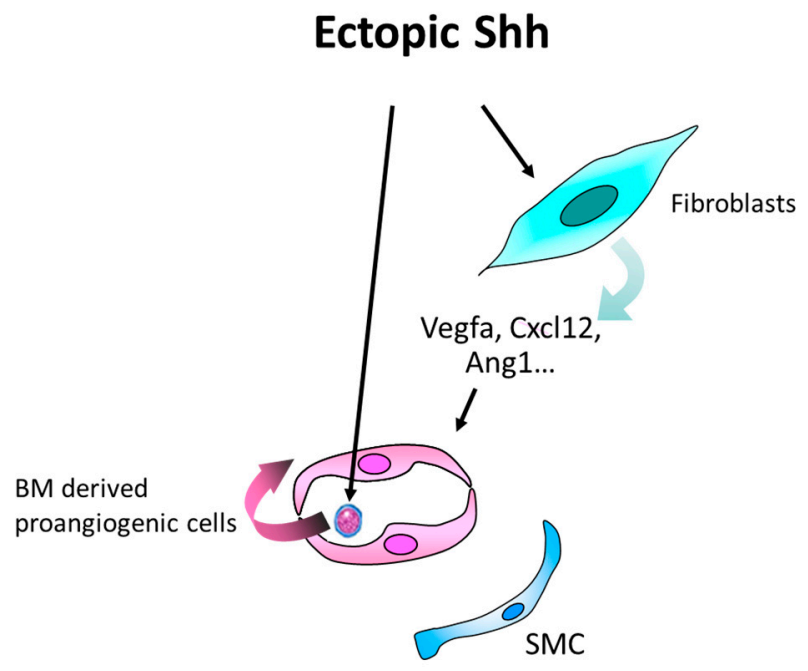

Angiogenesis

Figure 5. Schema representing the main cellular events underlying the proangiogenic effect of Shh therapy in the setting of ischemia. When administered ectopically in ischemic tissues, Shh promotes angiogenesis indirectly by upregulating Vegfa, Cxcl12, and Angpt1 in fibroblasts and by recruiting bone marrow-derived proangiogenic cells.

\subsubsection{Role of Hh Signaling in Other Ischemic Tissues}

The proangiogenic properties of the Hh ligands have been confirmed in other ischemic tissues including the heart [73,74], brain [75-77], skin [78], and peripheral nerves [79]. In each of these organs, administration of Shh (or a Smo agonist) increases capillary density after an ischemic insult. In line with the results obtained in the limb skeletal muscle, Shh-induced angiogenesis in the heart does not involve activation of Hh signaling in ECs [70]. On the contrary, Shh-induced angiogenesis has been associated with increased Vegfa levels in all these organs [73,76,78]. The role of the Vegfa in Shh-induced angiogenesis has been proven both in the skin [78] and in the brain [76] using anti-Vegfa antibodies and Shh has also been reported to promote the angiogenic capacity of the bone marrow derived cells in the heart [73,80] and in the skin [78].

Once again, the role of the endogenous Hh signaling in the heart is not clear, while Lavine $\mathrm{KJ}$ et al. reported that Hh-blocking antibodies administration decreases capillary density and cardiomyocyte survival in the setting of myocardial infarction [81], it has also been shown that cyclopamine administration ameliorates heart function [82].

\subsection{In the Setting of Cancer}

Hyperactivation of the Hh signaling observed in tumors is suggested to promote tumor angiogenesis. In detail, the Hh signaling blockade with Smo antagonists, including GDC-0449 and Cyclopamine, reduces the vascular density of Hh-producing colon cancer xenografts [60] and oral squamous cell carcinoma [83] or melanoma [84]. Conversely, ectopic expression of Shh in low-Hh-expressing DLD-1 xenografts increases tumor vascular density and augments angiogenesis [60] and the tumors implanted in Hhip+/- mice exhibit increased tumor angiogenesis [85]. Finally, high Gli1 expression levels have been correlated with increased microvascular density in Glioma [86] and high 
KDR expression in triple-negative breast cancers [87] while Ihh expression has been associated with Vegf expression and CD34 staining in hepatocellular carcinoma [88].

Hyperactivation of Hh signaling in cancer cells themselves (i.e., Gli1 or Shh overexpression) has been shown to increase proangiogenic factor expression including vegfa [86,89,90], matrix metallopeptidase 2 (MMP2), matrix metallopeptidase 9 (MMP9) [86], and heparanase [91] in glioma cells or cysteine-rich angiogenic inducer 61 (Cyr61) in breast cancer cells [92]. In particular, a novel alternatively spliced, truncated form of GLI1 (but not full-length GLI1) binds Vegfa promoter. Shh produced by cancer cells is proposed as an alternative to promote Vegfa expression in stromal fibroblasts $[60,85]$, which subsequently induces EC proliferation. Moreover, Hh ligands produced by cancer cells are also proposed to modulate EC function directly: Shh is highly expressed in human tongue oral squamous cell carcinoma (OSCC) whereas Ptch1, Gli1 and Gli2 proteins are expressed in the microvascular cells in the tumor invasive front $[83,93]$. In cultured HUVEC, Shh is reported to promote cell proliferation [84], while tGli1 promotes Vegfr2 expression [87] and Hhip, which is highly expressed in ECs, and is downregulated in ECs undergoing angiogenesis. These results suggest that a reduced expression of Hhip in tumor neovasculature may contribute to an increase Hh signaling within the tumor and may possibly promote angiogenesis [94]. Finally, Shh-derived from adeno-pancreatic cancer cells may promote the angiogenic properties of bone marrow derived progenitor cells [95] (Figure 6).

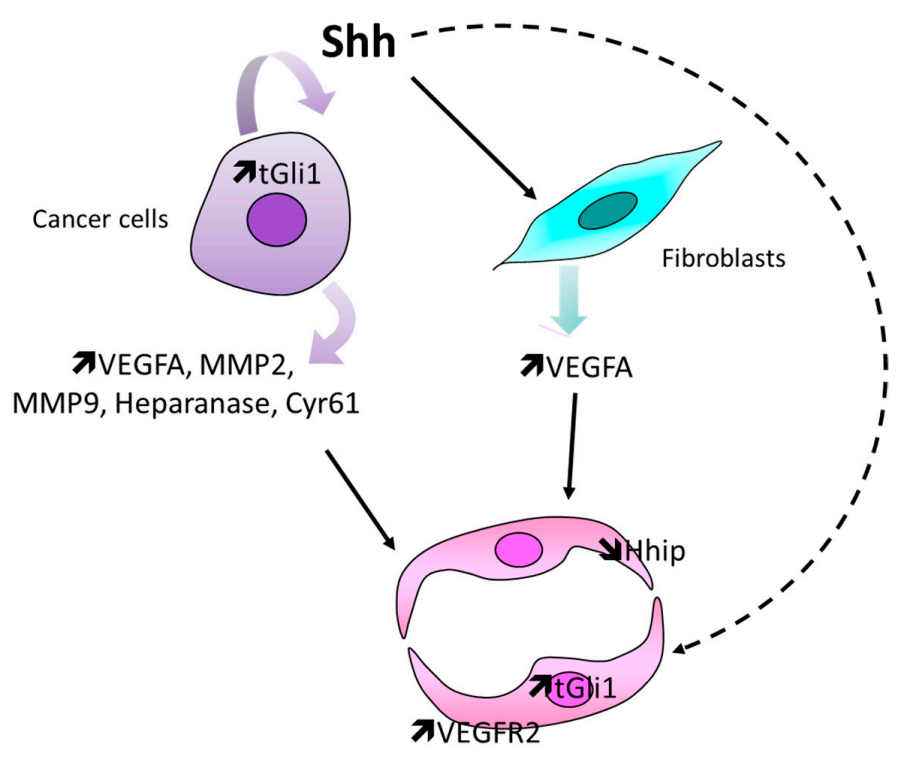

EC proliferation, angiogenesis

Figure 6. Schema representing the main cellular events involved in Hh-induced tumor angiogenesis. In tumors, Shh, which is mainly produced by cancer cells, may promote angiogenesis either by increasing proangiogenic factor expression in cancer cells themselves, by promoting Vegfa expression in stromal fibroblast, or by promoting EC proliferation directly through Gli1 upregulation.

Apart from being expressed by cancer cells, Hh ligands are also expressed by ECs (Shh and Ihh) $[93,96,97]$, especially in oral squamous cell carcinomas and gliomas, macrophages (Ihh) [93], and astrocytes [96]. Notably, inhibition of endothelial Scube2 suppresses tumor angiogenesis [98] and Shh may be carried by microvesicles especially from oral squamous cell carcinoma [99].

\section{Controversial Data}

While most studies agree in reporting that hyperactivated Hh signaling in tumors may promote tumor angiogenesis, a few studies have shown opposite results: first, Smo inhibition using IPI-926 has been reported to increase tumor vessel density in pancreatic ductal adenocarcinoma [100]. Shh-deficient 
tumors have been recently identified as more aggressive and exhibiting undifferentiated histology, increased vascularity, and heightened proliferation features that are fully recapitulated in control mice treated with IPI-926. Furthermore, administration of a Vegfr-blocking antibody selectively improves survival of Shh-deficient tumors, indicating that Hh-driven stroma suppresses tumor growth in part by restraining tumor angiogenesis [101]. Another Smo inhibitor-NVP-LDE225 (erismodegib)—has been shown to restore vascular density in pancreatic ductal adenocarcinoma, to decrease pericyte coverage and to enhance vessel permeability, suggesting an increased proportion of immature microvessels [102].

\subsection{Other Pathological Angiogenesis}

Hh signaling has been involved in atherosclerosis plaque angiogenesis. Insulin resistance adipocyte-derived exosomes (IRADEs) carry Shh, which promotes plaque vulnerability partially by inducing vasavasorum angiogenesis. This is associated with increased Gli1 and Vegfa expression levels [103]. In addition, Shh and Ptch1 are overexpressed in the eye both in retinopathy of prematurity (ROP) [47] and in laser-induced choroidal neovascularization [47,104], promoting pathological angiogenesis; inhibition of the Hh pathway (Cyclopamine) results in reduced angiogenesis and decreased Vegfa and Ptch1 levels, placing Shh activation upstream of Vegfa in experimental retinal angiogenesis [47]. Moreover, in mice with chronic liver injury or mice that underwent acute partial hepatectomy, administration of a Smo antagonist (GDC-0449 or Cyclopamine) prevents liver sinusoidal EC capillarization [105], and a study suggests that Annexin a2 may promote EC proliferation and angiogenesis by increasing Ihh and Gli1 in the setting of rheumatoid arthritis [106].

\section{Maintenance of Blood Vessel Integrity and Quiescence}

\subsection{At the Blood-Brain Barrier}

The critical role of Hh signaling in maintaining BBB integrity has first been highlighted in 2011 by Prat's laboratory [15]. This study revealed that the Hh signaling promotes BBB integrity both in embryos and in adults, since both $\mathrm{Shh}^{\mathrm{KO}}$ embryos and cyclopamine-administered adult mice display brain vascular leakage [15]. Interestingly, in this article, the same phenotype is recapitulated in Smo ${ }^{\mathrm{ECKO}}$ mice (Tie2-Cre; Smo ${ }^{\text {Flox/Flox }}$ ) demonstrating that ECs are the cells mediating Hh regulation of BBB integrity. Activation of the Hh signaling in ECs decreases BBB permeability and increases trans-endothelial electrical resistance of brain ECs by promoting expression of both tight (Claudin-3, Claudin-5 (Cldn5), Occludin, F11 receptor (Jam-A), (tight junction protein 1) ZO-1) [15,107], and adherens (Cadherin-5 (Cdh5), p120) [15] junction proteins. It is important to note that the upregulation of junction proteins has been associated with increased Gli1, SRY (sex-determining region Y)-box 18 (Sox18) [15,108], and Netrin1 [109] expression. Finally, Hh signaling is suggested to prevent EC activation, since Shh and purmorphamine have been shown to downregulate $\mathrm{Ccl} 2, \mathrm{C}-\mathrm{X}-\mathrm{C}$ motif chemokine ligand 8 (Cxcl8), and intercellular adhesion molecule 1 (Icam-1) expression in cultured brain ECs resulting in decreased CD4+ T cell adhesion and transmigration [15] (Figure 7).

We recently demonstrated that BBB integrity in adult mice depends on Dhh, which is produced by ECs themselves, using Dhh ${ }^{\mathrm{ECKO}}$ mice [110] (Figure 7), and BBB integrity is suggested to depend on Shh whom expression is reportedly modulated in several pathological conditions. Even though the role of astrocyte-derived Shh in maintaining BBB integrity in adults needs to be demonstrated using conditional KO mice, so far, it could be hypothesized that Dhh regulates BBB integrity in physiological conditions while Shh regulates it in certain pathological conditions. Indeed, Dhh is downregulated by inflammatory cytokines [110] while Shh is overexpressed in activated astrocytes in the setting of neuroinflammation (multiple sclerosis) [15], stroke [77,111], and subarachnoid hemorrhage. On the contrary, both Shh and Gli1 are decreased in HIV-associated dementia [112,113] and in the setting of forebrain stab injury [114]. Either ways, administration of Hh signaling agonists (rec NShh, SAG or Purmorphamine) have been shown to increase tight junction protein expression and to decrease BBB 
permeability $[77,111-113]$, while administration of a Smo antagonist increases BBB permeability or brain inflammation $[15,115]$.

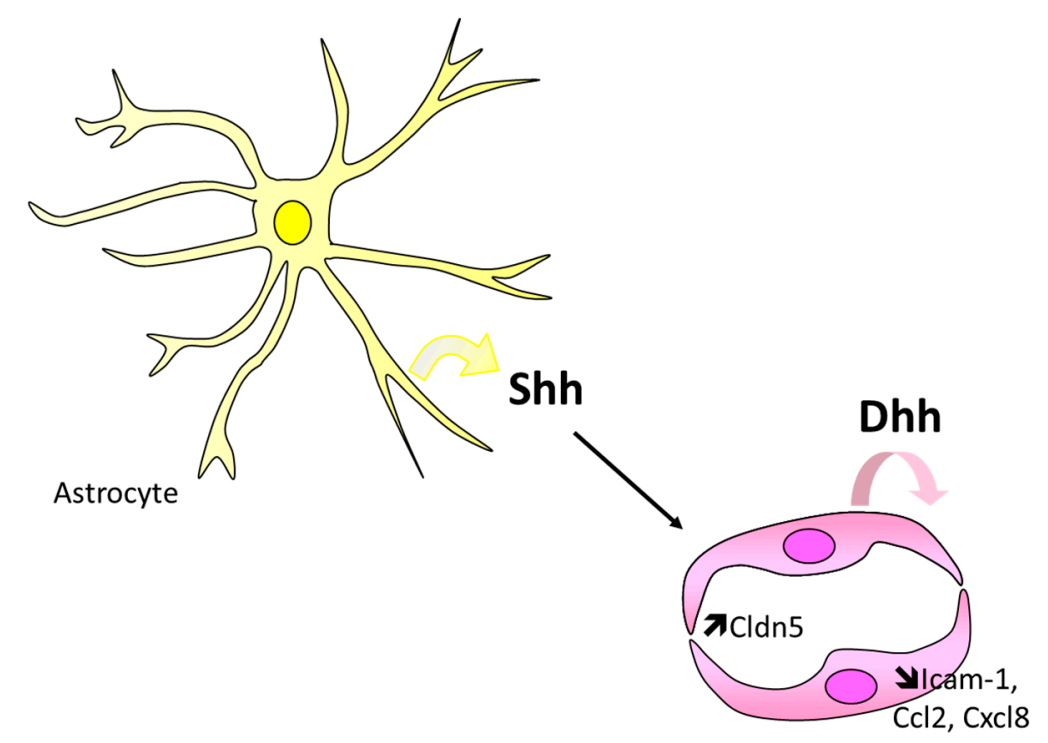

Maintenance of BBB integrity

Figure 7. Schema representing the main cellular events underlying Hh maintenance of BBB integrity. Activation of Hh signaling in brain ECs promotes thigh junction integrity by increasing Cldn 5 expression and BBB immune quiescence by downregulating Icam1, Ccl2, and Cxcl8. Brain ECs may either respond to Dhh, which is produced by EC themselves in physiological conditions, or to Shh, which is produced by astrocytes in certain pathological conditions.

These data are supported by few other in vitro studies in which astrocytes were co-cultured with brain ECs. The first study reports that the Smo agonist Purmorphamine decreases Mycobacterium tuberculosis-induced BBB disruption. Mycobacterium tuberculosis did not affect Shh astrocytic expression, but it decreases Scube2 expression and prevents Shh secretion [108]. In the second study, the Wip1 phosphatase prevents BBB breakdown and production of proinflammatory cytokines by increasing Shh and Gli1 expression [116]. Another article highlights the capacity of oxLDL to promote brain EC apoptosis by decreasing Shh-induced autocrine signaling [117]. As an alternative, Shh is proposed to promote BBB integrity by increasing Angpt1 expression autocrinally in astrocytes [111].

\section{Controversial Data}

A recent paper studying glioblastoma highlighted an opposite effect of the Hh signaling at the BBB. This study reports that "patient-derived glioblastoma-initiating cells" secrete Dhh, which interacts with endothelial Ptch2 via a paracrine mechanism to exacerbate BBB permeability [118]. Moreover, ectopic Shh overexpression in the dorsal neural tube has been shown to induce hypervascularization and hemorrhage in the spinal cord [10]. Another contradictory study reports that Shh carried by micro particles upregulated Icam-1 [119].

\subsection{At the Blood Nerve Barrier}

Activation of the Hh signaling in ECs is also shown to promote blood nerve barrier (BNB) integrity since $\mathrm{Smo}{ }^{\mathrm{ECKO}}$ mice display abnormal endoneurial capillary permeability and nerve inflammation [120]. Schwann cell-derived Dhh is suggested to be responsible for this effect [120,121]. As for the data obtained in the CNS, the Hh signaling is suggested to promote BNB integrity by increasing Cldn 5 and Ocln expression and by decreasing Ccl2 and interleukin 1 beta (Il1- $\beta$ ) expression [120,122]. 
Moreover, the increased BNB permeability associated with diabetic neuropathy has been shown to result from Dhh downregulation [120]. In the setting of chronic constriction injury (CCI), Shh expression is increased transiently, whereas Gli1 and Ptch1 expression are both decreased [122,123]. Finally, cyclopamine local administration mimic chronic constriction injury-induced vascular alterations including nerve inflammation and BNB opening [122] confirming the essential role of Hh signaling in promoting BNB integrity and preventing nerve inflammation.

\subsection{Outside of the Nervous System}

We recently reported that blood vessel integrity depends on $\mathrm{Hh}$ signaling not only within the central and peripheral nervous system, but also in other organs including the heart and the lung. Endothelial adherens junction integrity and immune quiescence depends on Dhh expression by ECs themselves. Indeed, $\mathrm{Dhh}^{\mathrm{ECKO}}$ mice display spontaneous vascular leakage and exacerbated LPS-induced neutrophil recruitment in the lung. Notably, Dhh is a downstream target of Klf2 which promotes interaction of the Cdh 5 with its partner the $\beta$-catenin and decreases Icam- 1 and vascular cell adhesion molecule 1 (Vcam-1) expression; nevertheless Dhh effects are more likely independent on Gli transcription factors since neither Gli1 nor Gli2 expression is modulated in Dhh KO ECs [110]. Interesting data show that Dhh, Shh, Gli1 and Ptch1 expression in ECs are downregulated by proinflammatory signals including tumor necrosis factor (TNF $\alpha$ ) and lipopolysaccharide (LPS), which contribute to LPS-induced EC dysfunction since treatment with Dhh or SAG can prevent TNF $\alpha$-induced increased capillary permeability and Vcam-1 expression [110,124].

Hh regulation of blood vessel survival, especially in the heart, is also proposed to depend on the Hh signaling activity in cardiomyocytes and on the resulting overexpression of Vegfa, Vegfb, Vegfc, Angpt1, and Angpt2 [81].

Finally, in the retina of Akika diabetic mice, the deceased expression of Shh has been associated with decreased Angpt1 expression, increased capillary permeability, and pericyte loss [125].

Apart from regulating endothelial intercellular junctions and endothelial immune quiescence, Hh ligands may also regulate vasoactive properties of ECs since administration of microparticles carrying Shh have been shown to promote both nitric oxide synthase 3 (NOS3) expression and NOS3 phosphorylation $[67,126]$. Moreover, microparticles carrying Shh correct ischemia/reperfusion [126] or Angiotensin-II induced-impaired vasorelaxation [127] and increased Hhip expression at the surface of endothelial-derived microparticles in the setting of acute graft-versus-host disease (aGVHD) promotes EC apoptosis, decreases NOS3 expression, and increases expression of ICAM-1 and VCAM-1 [128].

\subsection{Molecular Mechanism Involved in Hh-Induced Maintenance of Endothelium Integrity}

While Hh regulation of angiogenesis is mediated via Hh-induced upregulation of Vegfa in fibroblast-like cells, Hh regulation of blood vessel integrity seems to be cell-autonomous. Indeed, both $\mathrm{Smo}^{\mathrm{ECKO}}$ and $\mathrm{Dhh}^{\mathrm{ECKO}}$ mice are reported to display abnormal vessel permeability and several studies report expression of Hh ligands by ECs themselves: for instance, Shh is expressed by dental pulp and liver sinusoidal ECs $[105,129]$ and Ihh is expressed by ECs of the choroid in the mouse eye [130]. Finally, Hh ligands are shown to be expressed in tumor ECs $[93,96,97]$.

Nevertheless, signaling pathways mediating Hh-regulation of intercellular junctions or VCAM-1 expression are unknown. For instance, the Hh canonical signaling involvement (i.e. Gli dependant transcription) remains controversial while several study have reported Gli1 overexpression in ECs upon Shh treatment $[15,33,108]$, few others suggest that the Hh canonical signaling is not functional in ECs and that, on the contrary, Hh ligands signal through noncanonical signaling notably via the activation of the RhoA/ROCK [12,131-133] or PI3K/Akt pathways [12,134]. Upregulation of Gli1 in ECs may depends on the EC territory; indeed, Gli1 is shown to be over expressed either in brain $[15,108]$ or embryonic ECs [33].

The primary cilium is suggested to be necessary for BBB integrity since zebrafishes deficient for cilia biogenesis have increased risk of developmental intracranial hemorrhage which can be 
rescued either by activation of the Hh pathway (PKA dominant negative or Sufu KD) or by the endothelial-specific re-expression of intraflagellar transport genes [135]. However, neither adherens (Cdh5) nor tight junction proteins (ZO-1) are modulated in ift81 ${ }^{\text {hito9 }}$ mutant [135].

Finally, overexpression of Gli3, a negative regulator of Hh canonical signaling, in cultured ECs promotes Cxcl1, Cxcl2, Cxcl8, and TYMP expression. However, it is suggested to act independently from the Hh canonical pathway [65].

\section{Blood Vessel Maturation}

\subsection{Role of Hh Signaling in Mural Cell Recruitment and Differentiation}

Shh was suggested to promote muscularization and maturation of blood vessels in 2004, in a study showing that Shh gene therapy promotes the formation of enlarged and more muscularized vessels in diabetic nerves [79]. Such observation has been confirmed in the ischemic heart in 2011 [136] and fibroblast growth factor 9 (FGF9) has been shown to increase Shh expression in SMCs and the formation of stable vessels [137]. However, Smo inhibition by Cyclopamine inhibits pericyte coverage of newly formed capillary in the mouse cornea [14] and in the retina of Akika diabetic mice, the decreased expression of Shh has been associated with the downregulation of Angpt1 expression, pericyte loss, and an increased capillary permeability [125] (Figure 8).

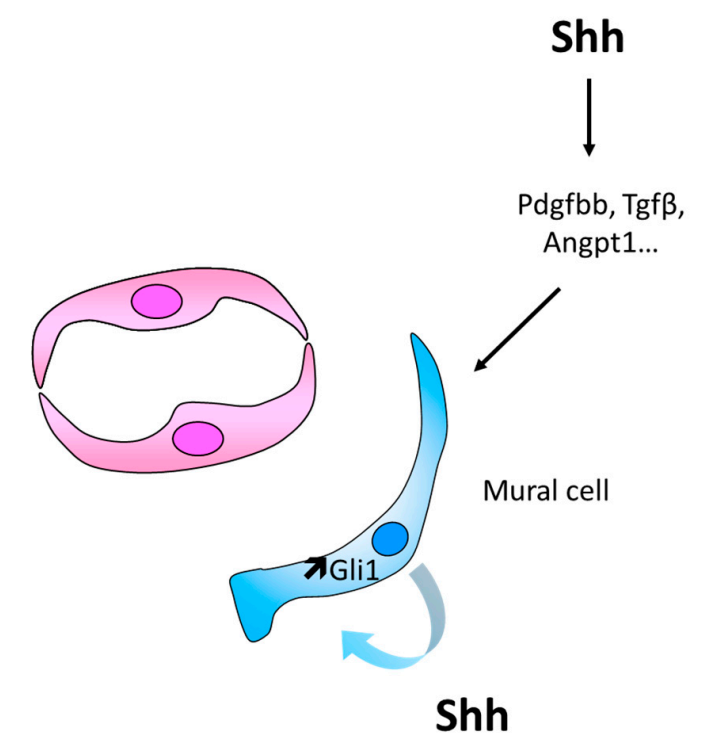

Mural cell differentiation, migration

Figure 8. Schema representing the main cellular events involved in Hh-induced mural cell recruitment and differentiation. Shh may either promote mural cell differentiation and migration indirectly by upregulating Angpt1, Pdgfbb, or Tgf $\beta$ in unidentified cells or by upregulating Gli1 directly in ECs.

Interestingly, both igu mutant and cyclopamine-treated zebrafish embryos display decreased mesenchymal Angpt1 expression and hemorrhages located in multiple tissues throughout the body including the somites and pharyngeal area and the head. Tight junctions between ECs display normal morphology and size in mutant embryos. On the contrary, perivascular mural cells fail to make contact with ECs. These results suggest that hemorrhage in igf fo10a mutants is not due to an EC structural defect but to a pericyte defect [46]. Nevertheless, while Kolesova et al. reported that administration of $5 \mathrm{E} 1$ blocking antibodies in zebrafish embryos results in hemorrhages, distribution of SMCs in the vessel wall is unchanged [39].

Muscularization of new blood vessels is more likely the consequence of a direct response of mural cells (SMCs or pericytes) to Hh signaling stimulation, since both SMCs and pericytes express Shh, 
Ptch1, Smo and Gli1 [14,137-139]. Indeed, Shh is shown to promote SMC proliferation $[140,141]$ and survival $[138,139,141]$. These effects are suggested to result from activation of Gli transcription factor directly $[139,141,142]$, from modulation of Notch signaling $[48,143,144]$ or activation of autophagy via Akt, phosphorylation [140]. Besides, Shh promotes SMC and pericyte migration $[14,145,146]$ through ERK1/2 and PI3KY activation [14]. Shh is also proposed either to maintain SMC differentiation [143] or to promote the differentiation of progenitor cells including Sca1+ adventitial resident stem cells [147-149] or bone marrow-derived mesenchymal stem cells [136] into SMCs. Similarly, in tooth, Shh activates Gli1 expression in peri-arterial cells, which give rise, at least in part, to NG2+ pericytes [150].

Differentiation of Sca1+ progenitor cells into SMCs has been shown to be mediated through Ptch1 and Gli2 [147]. Notably, one study reports that Shh, via Gli2 and Klf4, promotes VSMC dedifferentiation [151]. This last study is actually in accordance with studies reporting that Shh promotes SMC activation which is characterized by a proliferative and dedifferentiated state.

Finally, Shh increases the expression of factors promoting vessels stabilization such as Angpt1, platelet derived growth factor, BB dimer (Pdgf-BB), and transforming growth factor beta 1 (Tgf $\beta)[152,153]$.

\section{Controversial Data}

SIX homeobox 1 (Six) or EYA transcriptional coactivator and phosphatase 1 (Eya1) deficient embryos display an increased Shh expression especially because it fails to decrease after E16.5; these mutant embryos have severe vascular defects in the SMC compartment leading to the major vessel rupture and to hemorrhage. This is prevented when Shh expression is decreased (Eya1-/-; Shh+/embryos) [154,155]. Moreover, embryos expressing a constitutively active form of Smo in the ovary Mullerian duct have increased CD31-labeled endothelial tube; nevertheless, these vessels are not covered by SMCs [57].

\subsection{Role of Hh Signaling in Vascular Wall Remodeling}

Besides participating in blood vessel maturation, Hh signaling, especially Shh and Scube2, has been shown to be overexpressed in injured arteries especially during intimal formation after carotid artery ligation [144,156,157] or autogenous vein grafts [142] and in the hypoxic lung [139]. In both conditions, Shh upregulation is associated with SMC activation and proliferation. Conversely, Shh, Ptch1, and SMC expression are decreased in aneurysmal tissue samples [143]. At the molecular level, Shh expression in SMCs is increased by hypoxia [139], growth factors such as Pdgf-BB [14,151], heart-type fatty acid-binding proteins [145] and C1q/TNF-related protein-5 [146]. Pdgf-BB-induced Shh expression is shown to depend on ERK1/2 signaling pathway [151]. On the contrary Shh expression in SMCs is downregulated by shear stress $[48,141]$. Finally, one study reports a decreased Hh signaling activity (i.e., Gli1, Gli2 and Hhip downregulation) after carotid artery ligation. This is associated with SMC dedifferentiation [158].

\section{Discussion/Conclusion}

Altogether, these data highlight the wide actions of the Hh signaling in vascular biology. First, the Hh signaling is essential for angioblast assembly into vascular tubes, i.e., vasculogenesis. This has been observed in the yolk sac [29] and during the formation of the aorta [38]. Hh signaling is also involved in angiogenesis in embryos and in adults especially under pathological conditions including cancer and ischemia [61] and participates in vascular maturation including arterial differentiation [16] and capillary muscularization. Finally, the Hh signaling has been shown to promote vascular integrity by maintaining endothelial intercellular junctions both at the BBB [15] and in peripheral tissues [110].

While cellular and molecular mechanisms underlying the vascular effects of the Hh signaling remain elusive, some consensuses appear. Both Hh-driven vasculogenesis and angiogenesis more likely involve activation of mesenchymal-type cells. Vasculogenesis depends on the Hh-induced BMP4 overexpression in these third cells while Hh-induced angiogenesis is mediated by Vegfa upregulation. 
On the contrary Hh-induced endothelial barrier tightness seems to depend on the Hh signaling activation in ECs themselves.

However some mechanisms remain to be elucidated. Indeed, differentiation of angioblast is also suggested to depend on EC-activation by Hh ligands directly [33] and Hh-induced arterial differentiation is either proposed to depend on Vegfa upregulation in a third cell [16] or to be a direct consequence of the Hh signaling activation in ECs [43]. So far, very few studies have used cell specific conditional $\mathrm{KO}$ mice to investigate Hh-regulation of blood vessel biology which limits the accuracy of mechanistical insights; studies using EC-specific Smo KO mice show that both vascularization of the embryonic lung [35] and ischemia-induced angiogenesis in the adult hindlimb does not involve activation of the Hh signaling in ECs [62,70], while Hh-induced endothelial tightness in the nervous system does $[15,120]$. Nevertheless, the possible involvement of type I Hh noncanonical signaling, which does not require Smo, has not been considered. While in vivo studies strongly support an indirect regulation of angiogenesis by $\mathrm{Hh}$ ligands, multiple in vitro studies have reported that treatment of ECs with Hh ligands promoted EC migration [12,33,119,132,133], proliferation [132], 2D capillary morphogenesis [12,38,118,119,131,132,159], and EC sprouting [118], altogether suggesting that $\mathrm{Hh}$ ligands may promote angiogenesis via a direct action on EC, at least in certain organs or conditions.

Moreover, while Vegfa appears to be the main effector of Hh-induced angiogenesis, investigation of the regulation of Vegfa expression by the Hh signaling has been poorly investigated and limited to cancer cells. In breast cancer cells, Vegfa mRNA expression is shown to be specifically activated by a truncated form of Gli1 (splicing variant), while full-length Gli1 seems unable to bind Vegfa promoter and to activate its transcription [89]. Whether or not tGli1 is expressed in embryos or in adults in other cells than cancer cells is unknown.

Nevertheless, even if most studies agree in reporting that Hh signaling is proangiogenic, several conflicting data exist. Indeed, the endogenous Hh signaling has first been shown to promote ischemia-induced angiogenesis and systemic administration of Hh-blocking antibodies to decrease Vegfa mRNA levels and ischemic limb reperfusion [61]. However, later on, Gli3 knockdown which, on the contrary, induces increased activity of Hh canonical signaling, has also been shown to impair ischemic limb reperfusion $[65,69]$. Consistent with these two last studies, Shh deficiency has recently been associated to an indirect upregulation of Vegfa and to an accelerated ischemia-induced angiogenesis [66].

Therefore, further investigations are required to fully understand the role of the endogenous Hh signaling in the ischemic hindlimb. For instance, it would be interesting to compare the $\mathrm{Hh}$ signaling activity in mice administered with Hh-blocking antibodies and in mice deficient for Shh using reporter mice so that we could quantify the Hh signaling activity and Vegfa expression in different cell types. Indeed, while Pola et al. study involves the activation of the Hh signaling in fibroblast, studies conducted by Renault et al. investigated the role of the Hh signaling in myocytes [66,69]. It is important to note that Hh-blocking antibodies not only block Shh but also Ihh and Dhh activities [160].

Overall, the main reasons why mechanisms underlying the Hh action on the vasculature remain poorly understood are (1) lack of reliable, specific, and sensitive antibodies that could be used to detect expression of the Hh ligands and receptors so that we can identify Hh producing cells and Hh responding cells properly and (2) the limited amount of studies that have used tissue specific conditional KO mice. Moreover, the most widely used anti-Shh antibodies do also recognize Ihh and Dhh; this is the case of the rabbit anti-Shh antibodies (Santa-Cruz, sc-9024), goat anti-Shh antibodies (Santa-Cruz, sc-1194), and mouse anti-Shh antibodies (5E1, DHSB)). In fact, vascular effects induced by Hh ligands have been mainly attributed to Shh, while it may not be the case. For instance, Shh has been suggested to be the one promoting BBB tightness both in healthy and pathologic conditions [15], while a recent RNA single cell sequencing study shows that Dhh but not Shh and Thh is expressed within the gliovascular unit in the healthy adult brain [161].

The proangiogenic potential of the Hh signaling agonists is of growing interest in the treatment of ischemic diseases especially myocardial infarction and peripheral artery diseases as pointed out 
in several reviews [17-22]. However, it is a prerequisite to fully understand mechanisms driving the exogenous Hh part in the setting of ischemia-induced tissue injury, (1) because the role of the endogenous Hh signaling is still unclear and discordant and (2) because of the potential carcinogenic effect of Shh. This is why it is necessary to design therapies targeting specific signaling molecules that would promote revascularization of ischemic tissue but not carcinogenesis.

Moreover, in the light of more recent studies, Hh signaling agonists may be beneficial in the setting of diseases in which endothelium integrity is compromised notably cardiovascular diseases like diabetic microangiopathies and cerebrovascular disorders, such as multiple sclerosis and HIV-induced encephalopathy.

Author Contributions: S.G. and P.-L.H. wrote the manuscript; C.C. and M.-A.R. wrote and revised the manuscript. Acknowledgments: We thank Thierry Couffinhal and Alain-Pierre Gadeau for the critical re-reading of the manuscript.

Conflicts of Interest: The authors declare no conflicts of interest.

\section{References}

1. Nusslein-Volhard, C.; Wieschaus, E. Mutations affecting segment number and polarity in Drosophila. Nature 1980, 287, 795-801. [CrossRef] [PubMed]

2. Bitgood, M.J.; McMahon, A.P. Hedgehog and Bmp genes are coexpressed at many diverse sites of cell-cell interaction in the mouse embryo. Dev. Biol. 1995, 172, 126-138. [CrossRef] [PubMed]

3. Ramalho-Santos, M.; Melton, D.A.; McMahon, A.P. Hedgehog signals regulate multiple aspects of gastrointestinal development. Development 2000, 127, 2763-2772. [PubMed]

4. St-Jacques, B.; Hammerschmidt, M.; McMahon, A.P. Indian hedgehog signaling regulates proliferation and differentiation of chondrocytes and is essential for bone formation. Genes Dev. 1999, 13, 2072-2086. [CrossRef] [PubMed]

5. Bitgood, M.J.; Shen, L.; McMahon, A.P. Sertoli cell signaling by Desert hedgehog regulates the male germline. Curr. Biol. 1996, 6, 298-304. [CrossRef]

6. Parmantier, E.; Lynn, B.; Lawson, D.; Turmaine, M.; Namini, S.S.; Chakrabarti, L.; McMahon, A.P.; Jessen, K.R.; Mirsky, R. Schwann cell-derived Desert hedgehog controls the development of peripheral nerve sheaths. Neuron 1999, 23, 713-724. [CrossRef]

7. Petrova, R.; Joyner, A.L. Roles for Hedgehog signaling in adult organ homeostasis and repair. Development 2014, 141, 3445-3457. [CrossRef] [PubMed]

8. Scales, S.J.; de Sauvage, F.J. Mechanisms of Hedgehog pathway activation in cancer and implications for therapy. Trends Pharm. Sci. 2009, 30, 303-312. [CrossRef]

9. Pepicelli, C.V.; Lewis, P.M.; McMahon, A.P. Sonic hedgehog regulates branching morphogenesis in the mammalian lung. Curr. Biol. 1998, 8, 1083-1086. [CrossRef]

10. Rowitch, D.H.S.; Jacques, B.; Lee, S.M.; Flax, J.D.; Snyder, E.Y.; McMahon, A.P. Sonic hedgehog regulates proliferation and inhibits differentiation of CNS precursor cells. J. Neurosci. 1999, 19, 8954-8965. [CrossRef]

11. Pola, R.; Ling, L.E.; Silver, M.; Corbley, M.J.; Kearney, M.; Blake Pepinsky, R.; Shapiro, R.; Taylor, F.R.; Baker, D.P.; Asahara, T.; et al. The morphogen Sonic hedgehog is an indirect angiogenic agent upregulating two families of angiogenic growth factors. Nat. Med. 2001, 7, 706-711. [CrossRef]

12. Renault, M.A.; Roncalli, J.; Tongers, J.; Thorne, T.; Klyachko, E.; Misener, S.; Volpert, O.V.; Mehta, S.; Burg, A.; Luedemann, C.; et al. Sonic hedgehog induces angiogenesis via Rho kinase-dependent signaling in endothelial cells. J. Mol. Cell. Cardiol. 2010, 49, 490-498. [CrossRef] [PubMed]

13. Fujita, K.; Miyamoto, T.; Saika, S. Sonic hedgehog: Its expression in a healing cornea and its role in neovascularization. Mol. Vis. 2009, 15, 1036-1044. [PubMed]

14. Yao, Q.; Renault, M.A.; Chapouly, C.; Vandierdonck, S.; Belloc, I.; Jaspard-Vinassa, B.; Daniel-Lamaziere, J.M.; Laffargue, M.; Merched, A.; Desgranges, C.; et al. Sonic hedgehog mediates a novel pathway of PDGF-BB-dependent vessel maturation. Blood 2014, 123, 2429-2437. [CrossRef] [PubMed]

15. Alvarez, J.I.; Dodelet-Devillers, A.; Kebir, H.; Ifergan, I.; Fabre, P.J.; Terouz, S.; Sabbagh, M.; Wosik, K.; Bourbonniere, L.; Bernard, M.; et al. The Hedgehog Pathway Promotes Blood-Brain Barrier Integrity and CNS Immune Quiescence. Science 2011, 334, 1727-1731. [CrossRef] 
16. Lawson, N.D.; Vogel, A.M.; Weinstein, B.M. Sonic hedgehog and vascular endothelial growth factor act upstream of the Notch pathway during arterial endothelial differentiation. Dev. Cell 2002, 3, 127-136. [CrossRef]

17. Lavine, K.J.; Ornitz, D.M. Rebuilding the coronary vasculature: Hedgehog as a new candidate for pharmacologic revascularization. Trends Cardiovasc. Med. 2007, 17,77-83. [CrossRef]

18. Cristofaro, B.; Emanueli, C. Possible novel targets for therapeutic angiogenesis. Curr. Opin. Pharmacol. 2009, 9, 102-108. [CrossRef]

19. Pan, J.Y.; Zhou, S.H. The hedgehog signaling pathway, a new therapeutic target for treatment of ischemic heart disease. Pharmazie 2012, 67, 475-481.

20. Wang, Y.; Lu, P.; Zhao, D.; Sheng, J. Targeting the hedgehog signaling pathway for cardiac repair and regeneration. Herz 2017, 42, 662-668. [CrossRef]

21. Dunaeva, M.; Waltenberger, J. Hh signaling in regeneration of the ischemic heart. Cell. Mol. Life Sci. 2017, 74, 3481-3490. [CrossRef] [PubMed]

22. Salybekov, A.A.; Salybekova, A.K.; Pola, R.; Asahara, T. Sonic Hedgehog Signaling Pathway in Endothelial Progenitor Cell Biology for Vascular Medicine. Int. J. Mol. Sci. 2018, 19, 3040. [CrossRef] [PubMed]

23. Farzan, S.F.; Singh, S.; Schilling, N.S.; Robbins, D.J. Hedgehog Processing and Biological Activity. Am. J. Physiol. Gastrointest. Liver Physiol. 2008, 294, G844-G849. [CrossRef] [PubMed]

24. Pettigrew, C.A.; Asp, E.; Emerson, C.P. A new role for Hedgehogs in juxtacrine signaling. Mech. Dev. 2013, 131, 137-149. [CrossRef] [PubMed]

25. Tukachinsky, H.; Kuzmickas, R.P.; Jao, C.Y.; Liu, J.; Salic, A. Dispatched and scube mediate the efficient secretion of the cholesterol-modified hedgehog ligand. Cell Rep. 2012, 2, 308-320. [CrossRef] [PubMed]

26. Robbins, D.J.; Fei, D.L.; Riobo, N.A. The Hedgehog signal transduction network. Sci. Signal. 2012, 5, re6. [CrossRef] [PubMed]

27. Ramsbottom, S.A.; Pownall, M.E. Regulation of Hedgehog Signalling Inside and Outside the Cell. J. Dev. Biol. 2016, 4, 23. [CrossRef]

28. Bangs, F.; Anderson, K.V. Primary Cilia and Mammalian Hedgehog Signaling. Cold Spring Harb. Perspect Biol. 2017, 9, a028175. [CrossRef]

29. Byrd, N.; Becker, S.; Maye, P.; Narasimhaiah, R.; St-Jacques, B.; Zhang, X.; McMahon, J.; McMahon, A.; Grabel, L. Hedgehog is required for murine yolk sac angiogenesis. Development 2002, 129, 361-372.

30. Dyer, M.A.; Farrington, S.M.; Mohn, D.; Munday, J.R.; Baron, M.H. Indian hedgehog activates hematopoiesis and vasculogenesis and can respecify prospective neurectodermal cell fate in the mouse embryo. Development 2001, 128, 1717-1730.

31. Nagase, M.; Nagase, T.; Koshima, I.; Fujita, T. Critical time window of hedgehog-dependent angiogenesis in murine yolk sac. Microvasc. Res. 2006, 71, 85-90. [CrossRef] [PubMed]

32. Astorga, J.; Carlsson, P. Hedgehog induction of murine vasculogenesis is mediated by Foxf1 and Bmp4. Development 2007, 134, 3753-3761. [CrossRef] [PubMed]

33. Hochman, E.; Castiel, A.; Jacob-Hirsch, J.; Amariglio, N.; Izraeli, S. Molecular pathways regulating pro-migratory effects of Hedgehog signaling. J. Biol. Chem. 2006, 281, 33860-33870. [CrossRef] [PubMed]

34. Miller, L.-A.D.; Wert, S.E.; Clark, J.C.; Xu, Y.; Perl, A.-K.T.; Whitsett, J.A. Role of Sonic hedgehog in patterning of tracheal-bronchial cartilage and the peripheral lung. Dev. Dyn. 2004, 231, 57-71. [CrossRef] [PubMed]

35. White, A.C.; Lavine, K.J.; Ornitz, D.M. FGF9 and SHH regulate mesenchymal Vegfa expression and development of the pulmonary capillary network. Development 2007, 134, 3743-3752. [CrossRef]

36. van Tuyl, M.; Groenman, F.; Wang, J.; Kuliszewski, M.; Liu, J.; Tibboel, D.; Post, M. Angiogenic factors stimulate tubular branching morphogenesis of sonic hedgehog-deficient lungs. Dev. Biol. 2007, 303, 514-526. [CrossRef]

37. Seo, H.; Kim, J.; Park, G.-H.; Kim, Y.; Cho, S.-W. Long-range enhancers modulate Foxf1 transcription in blood vessels of pulmonary vascular network. Histochem. Cell Biol. 2016, 146, 289-300. [CrossRef]

38. Vokes, S.A.; Yatskievych, T.A.; Heimark, R.L.; McMahon, J.; McMahon, A.P.; Antin, P.B.; Krieg, P.A. Hedgehog signaling is essential for endothelial tube formation during vasculogenesis. Development 2004, 131, 4371-4380. [CrossRef]

39. Kolesova, H.; Roelink, H.; Grim, M. Sonic hedgehog is required for the assembly and remodeling of branchial arch blood vessels. Dev. Dyn 2008, 237, 1923-1934. [CrossRef] 
40. Moran, C.M.; Salanga, M.C.; Krieg, P.A. Hedgehog signaling regulates size of the dorsal aortae and density of the plexus during avian vascular development. Dev. Dyn. 2011, 240, 1354-1364. [CrossRef]

41. Coultas, L.; Nieuwenhuis, E.; Anderson, G.A.; Cabezas, J.; Nagy, A.; Henkelman, R.M.; Hui, C.C.; Rossant, J. Hedgehog regulates distinct vascular patterning events through VEGF-dependent and -independent mechanisms. Blood 2010, 116, 653-660. [CrossRef] [PubMed]

42. Brown, L.A.; Rodaway, A.R.; Schilling, T.F.; Jowett, T.; Ingham, P.W.; Patient, R.K.; Sharrocks, A.D. Insights into early vasculogenesis revealed by expression of the ETS-domain transcription factor Fli-1 in wild-type and mutant zebrafish embryos. Mech. Dev. 2000, 90, 237-252. [CrossRef]

43. Williams, C.; Kim, S.-H.; Ni, T.T.; Mitchell, L.; Ro, H.; Penn, J.S.; Baldwin, S.H.; Solnica-Krezel, L.; Zhong, T.P. Hedgehog signaling induces arterial endothelial cell formation by repressing venous cell fate. Dev. Biol. 2010, 341, 196-204. [CrossRef] [PubMed]

44. Nagase, T.; Nagase, M.; Yoshimura, K.; Machida, M.; Yamagishi, M. Defects in aortic fusion and craniofacial vasculature in the holoprosencephalic mouse embryo under inhibition of sonic hedgehog signaling. J. Craniofac. Surg. 2006, 17, 736-744. [CrossRef] [PubMed]

45. Nicoli, S.; Tobia, C.; Gualandi, L.; De Sena, G.; Presta, M. Calcitonin receptor-like receptor guides arterial differentiation in zebrafish. Blood 2008, 111, 4965-4972. [CrossRef]

46. Lamont, R.E.; Vu, W.; Carter, A.D.; Serluca, F.C.; MacRae, C.A.; Childs, S.J. Hedgehog signaling via angiopoietin1 is required for developmental vascular stability. Mech. Dev. 2010, 127, 159-168. [CrossRef]

47. Surace, E.M.; Balaggan, K.S.; Tessitore, A.; Mussolino, C.; Cotugno, G.; Bonetti, C.; Vitale, A.; Ali, R.R.; Auricchio, A. Inhibition of ocular neovascularization by hedgehog blockade. Mol. Ther. 2006, 13, 573-579. [CrossRef]

48. Walshe, T.E.; Connell, P.; Cryan, L.; Ferguson, G.; Gardiner, T.; Morrow, D.; Redmond, E.M.; O’Brien, C.; Cahill, P.A. Microvascular retinal endothelial and pericyte cell apoptosis in vitro: Role of hedgehog and Notch signaling. Investig. Ophthalmol. Vis. Sci. 2011, 52, 4472-4483. [CrossRef]

49. Berrios-Otero, C.A.; Wadghiri, Y.Z.; Nieman, B.J.; Joyner, A.L.; Turnbull, D.H. Three-dimensional micro-MRI analysis of cerebral artery development in mouse embryos. Magn. Reson. Med. 2009, 62, 1431-1439. [CrossRef]

50. Nielsen, C.M.; Dymecki, S.M. Sonic hedgehog is required for vascular outgrowth in the hindbrain choroid plexus. Dev. Biol. 2010, 340, 430-437. [CrossRef]

51. Colnot, C.; de la Fuente, L.; Huang, S.; Hu, D.; Lu, C.; St-Jacques, B.; Helms, J.A. Indian hedgehog synchronizes skeletal angiogenesis and perichondrial maturation with cartilage development. Development 2005, 132, 1057-1067. [CrossRef] [PubMed]

52. Dohle, E.; Fuchs, S.; Kolbe, M.; Hofmann, A.; Schmidt, H.; Kirkpatrick, C.J. Sonic hedgehog promotes angiogenesis and osteogenesis in a coculture system consisting of primary osteoblasts and outgrowth endothelial cells. Tissue Eng. Part A 2010, 16, 1235-1237. [CrossRef] [PubMed]

53. Duan, X.; Murata, Y.; Liu, Y.; Nicolae, C.; Olsen, B.R.; Berendsen, A.D. Vegfa regulates perichondrial vascularity and osteoblast differentiation in bone development. Development 2015, 142, 1984-1991. [CrossRef] [PubMed]

54. Lavine, K.J.; White, A.C.; Park, C.; Smith, C.S.; Choi, K.; Long, F.; Hui, C.C.; Ornitz, D.M. Fibroblast growth factor signals regulate a wave of Hedgehog activation that is essential for coronary vascular development. Genes Dev. 2006, 20, 1651-1666. [CrossRef] [PubMed]

55. Lavine, K.J.; Long, F.; Choi, K.; Smith, C.; Ornitz, D.M. Hedgehog signaling to distinct cell types differentially regulates coronary artery and vein development. Development 2008, 135, 3161-3171. [CrossRef]

56. Moran, C.M.; Myers, C.T.; Lewis, C.M.; Krieg, P.A. Hedgehog regulates angiogenesis of intersegmental vessels through the VEGF signaling pathway. Dev. Dyn. 2012, 241, 1034-1042. [CrossRef] [PubMed]

57. Ren, Y.; Cowan, R.G.; Migone, F.F.; Quirk, S.M. Overactivation of hedgehog signaling alters development of the ovarian vasculature in mice. Biol. Reprod. 2012, 86, 174. [CrossRef] [PubMed]

58. Weiss, O.; Kaufman, R.; Mishani, E.; Inbal, A. Ocular vessel patterning in zebrafish is indirectly regulated by Hedgehog signaling. Int. J. Dev. Biol. 2017, 61, 277-284. [CrossRef] [PubMed]

59. Davey, M.G.; James, J.; Paton, I.R.; Burt, D.W.; Tickle, C. Analysis of talpid3 and wild-type chicken embryos reveals roles for Hedgehog signalling in development of the limb bud vasculature. Dev. Biol. 2007, 301, 155-165. [CrossRef] [PubMed] 
60. Chen, W.; Tang, T.; Eastham-Anderson, J.; Dunlap, D.; Alicke, B.; Nannini, M.; Gould, S.; Yauch, R.; Modrusan, Z.; DuPree, K.J.; et al. Canonical hedgehog signaling augments tumor angiogenesis by induction of VEGF-A in stromal perivascular cells. Proc. Natl. Acad. Sci. USA 2011, 108, 9589-9594. [CrossRef]

61. Pola, R.; Ling, L.E.; Aprahamian, T.R.; Barban, E.; Bosch-Marce, M.; Curry, C.; Corbley, M.; Kearney, M.; Isner, J.M.; Losordo, D.W. Postnatal recapitulation of embryonic hedgehog pathway in response to skeletal muscle ischemia. Circulation 2003, 108, 479-485. [CrossRef] [PubMed]

62. Renault, M.A.; Chapouly, C.; Yao, Q.; Larrieu-Lahargue, F.; Vandierdonck, S.; Reynaud, A.; Petit, M.; Jaspard-Vinassa, B.; Belloc, I.; Traiffort, E.; et al. Desert hedgehog promotes ischemia-induced angiogenesis by ensuring peripheral nerve survival. Circ. Res. 2013, 112, 762-770. [CrossRef] [PubMed]

63. Palladino, M.; Gatto, I.; Neri, V.; Straino, S.; Silver, M.; Tritarelli, A.; Piccioni, A.; Smith, R.C.; Gaetani, E.; Losordo, D.W.; et al. Pleiotropic beneficial effects of sonic hedgehog gene therapy in an experimental model of peripheral limb ischemia. Mol. Ther. 2011, 19, 658-666. [CrossRef] [PubMed]

64. Renault, M.A.; Robbesyn, F.; Chapouly, C.; Yao, Q.; Vandierdonck, S.; Reynaud, A.; Belloc, I.; Traiffort, E.; Ruat, M.; Desgranges, C.; et al. Hedgehog-dependent regulation of angiogenesis and myogenesis is impaired in aged mice. Arter. Thromb. Vasc. Biol. 2013, 33, 2858-2866. [CrossRef] [PubMed]

65. Renault, M.A.; Roncalli, J.; Tongers, J.; Misener, S.; Thorne, T.; Jujo, K.; Ito, A.; Clarke, T.; Fung, C.; Millay, M.; et al. The Hedgehog transcription factor Gli3 modulates angiogenesis. Circ. Res. 2009, 105, 818-826. [CrossRef] [PubMed]

66. Caradu, C.; Guy, A.; James, C.; Reynaud, A.; Gadeau, A.-P.; Renault, M.-A. Endogenous Sonic Hedgehog limits inflammation and angiogenesis in the ischaemic skeletal muscle of mice. Cardiovasc. Res. 2018, 114, 759-770. [CrossRef]

67. Benameur, T.; Soleti, R.; Porro, C.; Andriantsitohaina, R.; Martínez, M.C. Microparticles carrying Sonic hedgehog favor neovascularization through the activation of nitric oxide pathway in mice. PLOS ONE 2010, 5, e12688. [CrossRef]

68. Qin, Y.; He, Y.-H.; Hou, N.; Zhang, G.-S.; Cai, Y.; Zhang, G.-P.; Xiao, Q.; He, L.-S.; Li, S.-J.; Yi, Q.; et al. Sonic hedgehog improves ischemia-induced neovascularization by enhancing endothelial progenitor cell function in type 1 diabetes. Mol. Cell. Endocrinol. 2016, 423, 30-39. [CrossRef]

69. Renault, M.A.; Vandierdonck, S.; Chapouly, C.; Yu, Y.; Qin, G.; Metras, A.; Couffinhal, T.; Losordo, D.W.; Yao, Q.; Reynaud, A.; et al. Gli3 regulation of myogenesis is necessary for ischemia-induced angiogenesis. Circ. Res. 2013, 113, 1148-1158. [CrossRef]

70. Gupta, R.; Mackie, A.R.; Misener, S.; Liu, L.; Losordo, D.W.; Kishore, R. Endothelial smoothened-dependent hedgehog signaling is not required for sonic hedgehog induced angiogenesis or ischemic tissue repair. Lab. Investig. 2018, 98, 682-691. [CrossRef]

71. Straface, G.; Aprahamian, T.; Flex, A.; Gaetani, E.; Biscetti, F.; Smith, R.C.; Pecorini, G.; Pola, E.; Angelini, F.; Stigliano, E.; et al. Sonic hedgehog regulates angiogenesis and myogenesis during post-natal skeletal muscle regeneration. J. Cell. Mol. Med. 2009, 13, 2424-2435. [CrossRef] [PubMed]

72. Piccioni, A.; Gaetani, E.; Neri, V.; Gatto, I.; Palladino, M.; Silver, M.; Smith, R.C.; Giarretta, I.; Pola, E.; Hlatky, L.; et al. Sonic Hedgehog Therapy in a Mouse Model of Age-Associated Impairment of Skeletal Muscle Regeneration. J. Gerontol. 2013, 69, 245-252. [CrossRef] [PubMed]

73. Kusano, K.F.; Pola, R.; Murayama, T.; Curry, C.; Kawamoto, A.; Iwakura, A.; Shintani, S.; Ii, M.; Asai, J.; Tkebuchava, T.; et al. Sonic hedgehog myocardial gene therapy: Tissue repair through transient reconstitution of embryonic signaling. Nat. Med. 2005, 11, 1197-1204. [CrossRef] [PubMed]

74. Ahmed, R.P.H.; Haider, K.H.; Shujia, J.; Afzal, M.R.; Ashraf, M. Sonic Hedgehog gene delivery to the rodent heart promotes angiogenesis via iNOS/netrin-1/PKC pathway. PLoS ONE 2010, 5, e8576. [CrossRef] [PubMed]

75. Jin, Y.; Barnett, A.; Zhang, Y.; Yu, X.; Luo, Y. Poststroke Sonic Hedgehog Agonist Treatment Improves Functional Recovery by Enhancing Neurogenesis and Angiogenesis. Stroke 2017, 48, 1636-1645. [CrossRef] [PubMed]

76. Chen, S.-C.; Huang, M.; He, Q.-W.; Zhang, Y.; Opoku, E.N.; Yang, H.; Jin, H.-J.; Xia, Y.-P.; Hu, B. Administration of sonic hedgehog protein induces angiogenesis and has therapeutic effects after stroke in rats. Neuroscience 2017, 352, 285-295. [CrossRef] [PubMed] 
77. Chechneva, O.V.; Mayrhofer, F.; Daugherty, D.J.; Krishnamurty, R.G.; Bannerman, P.; Pleasure, D.E.; Deng, W. A Smoothened receptor agonist is neuroprotective and promotes regeneration after ischemic brain injury. Cell Death Dis. 2014, 5, e1481. [CrossRef] [PubMed]

78. Asai, J.; Takenaka, H.; Kusano, K.F.; Ii, M.; Luedemann, C.; Curry, C.; Eaton, E.; Iwakura, A.; Tsutsumi, Y.; Hamada, H.; et al. Topical sonic hedgehog gene therapy accelerates wound healing in diabetes by enhancing endothelial progenitor cell-mediated microvascular remodeling. Circulation 2006, 113, 2413-2424. [CrossRef] [PubMed]

79. Kusano, K.F.; Allendoerfer, K.L.; Munger, W.; Pola, R.; Bosch-Marce, M.; Kirchmair, R.; Yoon, Y.S.; Curry, C.; Silver, M.; Kearney, M.; et al. Sonic hedgehog induces arteriogenesis in diabetic vasa nervorum and restores function in diabetic neuropathy. Arter. Thromb. Vasc. Biol. 2004, 24, 2102-2107. [CrossRef]

80. Bueno-Betí, C.; Novella, S.; Soleti, R.; Mompeón, A.; Vergori, L.; Sanchís, J.; Andriantsitohaina, R.; Martínez, M.C.; Hermenegildo, C. Microparticles Harboring Sonic Hedgehog Morphogen Improve the Vasculogenesis Capacity of Endothelial Progenitor Cells Derived from Myocardial Infarction Patients. Cardiovasc. Res. 2018, 115, 409-418. [CrossRef] [PubMed]

81. Lavine, K.J.; Kovacs, A.; Ornitz, D.M. Hedgehog signaling is critical for maintenance of the adult coronary vasculature in mice. J. Clin. Investig. 2008, 118, 2404-2414. [CrossRef] [PubMed]

82. Bijlsma, M.F.; Leenders, P.J.; Janssen, B.J.; Peppelenbosch, M.P.; Ten Cate, H.; Spek, C.A. Endogenous hedgehog expression contributes to myocardial ischemia-reperfusion-induced injury. Exp. Biol. Med. 2008, 233, 989-996. [CrossRef] [PubMed]

83. Kuroda, H.; Kurio, N.; Shimo, T.; Matsumoto, K.; Masui, M.; Takabatake, K.; Okui, T.; Ibaragi, S.; Kunisada, Y.; Obata, K.; et al. Oral Squamous Cell Carcinoma-derived Sonic Hedgehog Promotes Angiogenesis. Anticancer Res. 2017, 37, 6731-6737. [PubMed]

84. Geng, L.; Cuneo, K.C.; Cooper, M.K.; Wang, H.; Sekhar, K.; Fu, A.; Hallahan, D.E. Hedgehog signaling in the murine melanoma microenvironment. Angiogenesis 2007, 10, 259-267. [CrossRef]

85. Agrawal, V.; Kim, D.Y.; Kwon, Y.G. Hhip regulates tumor-stroma-mediated upregulation of tumor angiogenesis. Exp. Mol. Med. 2017, 49, e289. [CrossRef] [PubMed]

86. Cui, D.; Chen, X.; Yin, J.; Wang, W.; Lou, M.; Gu, S. Aberrant activation of Hedgehog/Gli1 pathway on angiogenesis in gliomas. Neurol India 2012, 60, 589-596. [PubMed]

87. Di Mauro, C.; Rosa, R.; D’Amato, V.; Ciciola, P.; Servetto, A.; Marciano, R.; Orsini, R.C.; Formisano, L.; De Falco, S.; Cicatiello, V.; et al. Hedgehog signalling pathway orchestrates angiogenesis in triple-negative breast cancers. Br. J. Cancer 2017, 116, 1425-1435. [CrossRef]

88. Li, Y.; Liu, Y.; Wang, G.; Wang, Y.; Guo, L. Cooperation of Indian Hedgehog and Vascular Endothelial Growth Factor in Tumor Angiogenesis and Growth in Human Hepatocellular Carcinomas, an Immunohistochemical Study. Appl. Immunohistochem. Mol. Morphol. 2018. [CrossRef]

89. Cao, X.; Geradts, J.; Dewhirst, M.W.; Lo, H.W. Upregulation of VEGF-A and CD24 gene expression by the tGLI1 transcription factor contributes to the aggressive behavior of breast cancer cells. Oncogene 2012, 31, 104-115. [CrossRef]

90. Liao, X.; Siu, M.K.; Au, C.W.; Wong, E.S.; Chan, H.Y.; Ip, P.P.; Ngan, H.Y.; Cheung, A.N. Aberrant activation of hedgehog signaling pathway in ovarian cancers: Effect on prognosis, cell invasion and differentiation. Carcinogenesis 2009, 30, 131-140. [CrossRef]

91. Zhu, H.; Carpenter, R.L.; Han, W.; Lo, H.W. The GLI1 splice variant TGLI1 promotes glioblastoma angiogenesis and growth. Cancer Lett. 2014, 343, 51-61. [CrossRef] [PubMed]

92. Harris, L.G.; Pannell, L.K.; Singh, S.; Samant, R.S.; Shevde, L.A. Increased vascularity and spontaneous metastasis of breast cancer by hedgehog signaling mediated upregulation of cyr61. Oncogene 2012, 31, 3370-3380. [CrossRef] [PubMed]

93. de Faro Valverde, L.; de Almeida Pereira, T.; Dias, R.B.; Guimaraes, V.S.; Ramos, E.A.; Santos, J.N.; Gurgel Rocha, C.A. Macrophages and endothelial cells orchestrate tumor-associated angiogenesis in oral cancer via hedgehog pathway activation. Tumour Biol. 2016, 37, 9233-9241. [CrossRef] [PubMed]

94. Olsen, C.L.; Hsu, P.P.; Glienke, J.; Rubanyi, G.M.; Brooks, A.R. Hedgehog-interacting protein is highly expressed in endothelial cells but down-regulated during angiogenesis and in several human tumors. BMC Cancer 2004, 4, 43. [CrossRef] [PubMed] 
95. Yamazaki, M.; Nakamura, K.; Mizukami, Y.; Ii, M.; Sasajima, J.; Sugiyama, Y.; Nishikawa, T.; Nakano, Y.; Yanagawa, N.; Sato, K.; et al. Sonic hedgehog derived from human pancreatic cancer cells augments angiogenic function of endothelial progenitor cells. Cancer Sci. 2008, 99, 1131-1138. [CrossRef] [PubMed]

96. Becher, O.J.; Hambardzumyan, D.; Fomchenko, E.I.; Momota, H.; Mainwaring, L.; Bleau, A.M.; Katz, A.M.; Edgar, M.; Kenney, A.M.; Cordon-Cardo, C.; et al. Gli activity correlates with tumor grade in platelet-derived growth factor-induced gliomas. Cancer Res. 2008, 68, 2241-2249. [CrossRef] [PubMed]

97. Yan, G.N.; Yang, L.; Lv, Y.F.; Shi, Y.; Shen, L.L.; Yao, X.H.; Guo, Q.N.; Zhang, P.; Cui, Y.H.; Zhang, X.; et al. Endothelial cells promote stem-like phenotype of glioma cells through activating the Hedgehog pathway. J. Pathol. 2014, 234, 11-22. [CrossRef]

98. Lin, Y.-C.; Liu, C.-Y.; Kannagi, R.; Yang, R.-B. Inhibition of Endothelial SCUBE2 (Signal Peptide-CUB-EGF Domain-Containing Protein 2), a Novel VEGFR2 (Vascular Endothelial Growth Factor Receptor 2) Coreceptor, Suppresses Tumor Angiogenesis. Arter. Thromb. Vasc. Biol. 2018, 38, 1202-1215. [CrossRef]

99. Huaitong, X.; Yuanyong, F.; Yueqin, T.; Peng, Z.; Wei, S.; Kai, S. Microvesicles releasing by oral cancer cells enhance endothelial cell angiogenesis via Shh/RhoA signaling pathway. Cancer Biol. 2017, 18, 783-791. [CrossRef]

100. Olive, K.P.; Jacobetz, M.A.; Davidson, C.J.; Gopinathan, A.; McIntyre, D.; Honess, D.; Madhu, B.; Goldgraben, M.A.; Caldwell, M.E.; Allard, D.; et al. Inhibition of Hedgehog signaling enhances delivery of chemotherapy in a mouse model of pancreatic cancer. Science 2009, 324, 1457-1461. [CrossRef]

101. Rhim, A.D.; Oberstein, P.E.; Thomas, D.H.; Mirek, E.T.; Palermo, C.F.; Sastra, S.A.; Dekleva, E.N.; Saunders, T.; Becerra, C.P.; Tattersall, I.W.; et al. Stromal elements act to restrain, rather than support, pancreatic ductal adenocarcinoma. Cancer Cell 2014, 25, 735-747. [CrossRef] [PubMed]

102. Roy Chaudhuri, T.; Straubinger, N.L.; Pitoniak, R.F.; Hylander, B.L.; Repasky, E.A.; Ma, W.W.; Straubinger, R.M. Tumor-Priming Smoothened Inhibitor Enhances Deposition and Efficacy of Cytotoxic Nanoparticles in a Pancreatic Cancer Model. Mol. Cancer 2016, 15, 84-93. [CrossRef] [PubMed]

103. Wang, F.; Chen, F.-F.; Shang, Y.-Y.; Li, Y.; Wang, Z.-H.; Han, L.; Li, Y.-H.; Zhang, L.; Ti, Y.; Zhang, W.; et al. Insulin resistance adipocyte-derived exosomes aggravate atherosclerosis by increasing vasa vasorum angiogenesis in diabetic ApoE-/-mice. Int. J. Cardiol. 2018, 265, 181-187. [CrossRef] [PubMed]

104. He, H.; Zhang, H.; Li, B.; Li, G.; Wang, Z. Blockade of the sonic hedgehog signalling pathway inhibits choroidal neovascularization in a laser-induced rat model. J. Huazhong Univ. Sci. Technol. Med. Sci. 2010, 30, 659-665. [CrossRef] [PubMed]

105. Xie, G.; Choi, S.S.; Syn, W.-K.; Michelotti, G.A.; Swiderska, M.; Karaca, G.; Chan, I.S.; Chen, Y.; Diehl, A.M. Hedgehog signalling regulates liver sinusoidal endothelial cell capillarisation. Gut 2013, 62, 299-309. [CrossRef] [PubMed]

106. Yi, J.; Zhu, Y.; Jia, Y.; Jiang, H.; Zheng, X.; Liu, D.; Gao, S.; Sun, M.; Hu, B.; Jiao, B.; et al. The Annexin a2 Promotes Development in Arthritis through Neovascularization by Amplification Hedgehog Pathway. PLoS ONE 2016, 11, e0150363. [CrossRef] [PubMed]

107. Wang, Y.; Jin, S.; Sonobe, Y.; Cheng, Y.; Horiuchi, H.; Parajuli, B.; Kawanokuchi, J.; Mizuno, T.; Takeuchi, H.; Suzumura, A. Interleukin-1 $\beta$ Induces Blood-Brain Barrier Disruption by Downregulating Sonic Hedgehog in Astrocytes. PLoS ONE 2014, 9, e110024. [CrossRef] [PubMed]

108. Brilha, S.; Ong, C.W.M.; Weksler, B.; Romero, N.; Couraud, P.-O.; Friedland, J.S. Matrix metalloproteinase-9 activity and a downregulated Hedgehog pathway impair blood-brain barrier function in an in vitro model of CNS tuberculosis. Sci. Rep. 2017, 7, 16031. [CrossRef] [PubMed]

109. Podjaski, C.; Alvarez, J.I.; Bourbonniere, L.; Larouche, S.; Terouz, S.; Bin, J.M.; Lécuyer, M.-A.; Saint-Laurent, O.; Larochelle, C.; Darlington, P.J.; et al. Netrin 1 regulates blood-brain barrier function and neuroinflammation. Brain 2015, 138, 1598-1612. [CrossRef]

110. Caradu, C.; Couffinhal, T.; Chapouly, C.; Guimbal, S.; Hollier, P.-L.; Ducasse, E.; Bura-Rivière, A.; Dubois, M.; Gadeau, A.-P.; Renault, M.-A. Restoring Endothelial Function by Targeting Desert Hedgehog Downstream of Klf2 Improves Critical Limb Ischemia in Adults. Circ. Res. 2018, 123, 1053-1065. [CrossRef]

111. Xia, Y.; He, Q.; Li, Y.; Chen, S.; Huang, M.; Wang, Y.; Gao, Y.; Huang, Y.; Wang, M.; Mao, L.; et al. Recombinant Human Sonic Hedgehog Protein Regulates the Expression of ZO-1 and Occludin by Activating Angiopoietin-1 in Stroke Damage. PLoS ONE 2013, 8, e68891. [CrossRef] [PubMed] 
112. Singh, V.B.; Singh, M.V.; Gorantla, S.; Poluektova, L.Y.; Maggirwar, S.B. Smoothened Agonist Reduces Human Immunodeficiency Virus Type-1-Induced Blood-Brain Barrier Breakdown in Humanized Mice. Sci. Rep. 2016, 6, 26876. [CrossRef] [PubMed]

113. Singh, V.B.; Singh, M.V.; Piekna-Przybylska, D.; Gorantla, S.; Poluektova, L.Y.; Maggirwar, S.B. Sonic Hedgehog mimetic prevents leukocyte infiltration into the CNS during acute HIV infection. Sci. Rep. 2017, 7, 9578. [CrossRef] [PubMed]

114. Allahyari, R.V.; Clark, K.L.; Shepard, K.A.; Garcia, A.D.R. Sonic hedgehog signaling is negatively regulated in reactive astrocytes after forebrain stab injury. Sci Rep. 2019, 9, 565. [CrossRef] [PubMed]

115. Li, T.; Zhang, J.; Liu, R.Y.; Lian, Z.G.; Chen, X.L.; Ma, L.; Sun, H.M.; Zhao, Y.L. The role of the sonic hedgehog signaling pathway in early brain injury after experimental subarachnoid hemorrhage in rats. Neurosci. Lett. 2013, 552, 81-86. [CrossRef]

116. Zhen, H.; Zhao, L.; Ling, Z.; Kuo, L.; Xue, X.; Feng, J. Wip1 regulates blood-brain barrier function and neuro-inflammation induced by lipopolysaccharide via the sonic hedgehog signaling signaling pathway. Mol. Immunol. 2018, 93, 31-37. [CrossRef] [PubMed]

117. Jiang, X.-L.; Chen, T.; Zhang, X. Activation of sonic hedgehog signaling attenuates oxidized low-density lipoprotein-stimulated brain microvascular endothelial cells dysfunction in vitro. Int. J. Clin. Exp. Pathol. 2015, 8, 12820-12828.

118. Azzi, S.; Treps, L.; Leclair, H.M.; Ngo, H.-M.; Harford-Wright, E.; Gavard, J. Desert Hedgehog/Patch2 Axis Contributes to Vascular Permeability and Angiogenesis in Glioblastoma. Front. Pharm. 2015, 6, 281. [CrossRef]

119. Soleti, R.; Benameur, T.; Porro, C.; Panaro, M.A.; Andriantsitohaina, R.; Martínez, M.C. Microparticles harboring Sonic Hedgehog promote angiogenesis through the upregulation of adhesion proteins and proangiogenic factors. Carcinogenesis 2009, 30, 580-588. [CrossRef]

120. Chapouly, C.; Yao, Q.; Vandierdonck, S.; Larrieu-Lahargue, F.; Mariani, J.N.; Gadeau, A.-P.; Renault, M.-A. Impaired Hedgehog signalling-induced endothelial dysfunction is sufficient to induce neuropathy: Implication in diabetes. Cardiovasc. Res. 2016, 109, 217-227. [CrossRef]

121. Sharghi-Namini, S.; Turmaine, M.; Meier, C.; Sahni, V.; Umehara, F.; Jessen, K.R.; Mirsky, R. The Structural and Functional Integrity of Peripheral Nerves Depends on the Glial-Derived Signal Desert Hedgehog. J. Neurosci. 2006, 26, 6364-6376. [CrossRef] [PubMed]

122. Moreau, N.; Mauborgne, A.; Bourgoin, S.; Couraud, P.-O.; Romero, I.A.; Weksler, B.B.; Villanueva, L.; Pohl, M.; Boucher, Y. Early alterations of Hedgehog signaling pathway in vascular endothelial cells after peripheral nerve injury elicit blood-nerve barrier disruption, nerve inflammation, and neuropathic pain development. Pain 2016, 157, 827-839. [CrossRef] [PubMed]

123. Moreau, N.; Dieb, W.; Mauborgne, A.; Bourgoin, S.; Villanueva, L.; Pohl, M.; Boucher, Y. Hedgehog Pathway-Mediated Vascular Alterations Following Trigeminal Nerve Injury. J. Dent. Res. 2017, 96, 450-457. [CrossRef] [PubMed]

124. Yang, Y.; Li, Q.; Deng, Z.; Zhang, Z.; Xu, J.; Qian, G.; Wang, G. Protection from lipopolysaccharide-induced pulmonary microvascular endothelial cell injury by activation of hedgehog signaling pathway. Mol. Biol. Rep. 2011, 38, 3615-3622. [CrossRef] [PubMed]

125. Huang, H.; He, J.; Johnson, D.; Wei, Y.; Liu, Y.; Wang, S.; Lutty, G.A.; Duh, E.J.; Semba, R.D. Deletion of placental growth factor prevents diabetic retinopathy and is associated with Akt activation and HIF1 $\alpha$-VEGF pathway inhibition. Diabetes 2015, 64, 200-212. [CrossRef] [PubMed]

126. Agouni, A.; Mostefai, H.A.; Porro, C.; Carusio, N.; Favre, J.; Richard, V.; Henrion, D.; Martínez, M.C.; Andriantsitohaina, R. Sonic hedgehog carried by microparticles corrects endothelial injury through nitric oxide release. FASEB J. 2007, 21, 2735-2741. [CrossRef] [PubMed]

127. Marrachelli, V.G.; Mastronardi, M.L.; Sarr, M.; Soleti, R.; Leonetti, D.; Martínez, M.C.; Andriantsitohaina, R. Sonic hedgehog carried by microparticles corrects angiotensin II-induced hypertension and endothelial dysfunction in mice. PLoS ONE 2013, 8, e72861. [CrossRef]

128. Nie, D.M.; Wu, Q.L.; Zheng, P.; Chen, P.; Zhang, R.; Li, B.B.; Fang, J.; Xia, L.H.; Hong, M. Endothelial microparticles carrying hedgehog-interacting protein induce continuous endothelial damage in the pathogenesis of acute graft-versus-host disease. Am. J. Physiol. Cell Physiol. 2016, 310, C821-C835. [CrossRef] 
129. Farahani, R.M.; Sarrafpour, B.; Simonian, M.; Li, Q.; Hunter, N. Directed glia-assisted angiogenesis in a mature neurosensory structure: Pericytes mediate an adaptive response in human dental pulp that maintains blood-barrier function. J. Comp. Neurol. 2012, 520, 3803-3826. [CrossRef]

130. Dakubo, G.D.; Mazerolle, C.; Furimsky, M.; Yu, C.; St-Jacques, B.; McMahon, A.P.; Wallace, V.A. Indian hedgehog signaling from endothelial cells is required for sclera and retinal pigment epithelium development in the mouse eye. Dev. Biol. 2008, 320, 242-255. [CrossRef]

131. Chinchilla, P.; Xiao, L.; Kazanietz, M.G.; Riobo, N.A. Hedgehog proteins activate pro-angiogenic responses in endothelial cells through non-canonical signaling pathways. Cell Cycle 2010, 9, 570-579. [CrossRef] [PubMed]

132. He, Q.-W.; Xia, Y.-P.; Chen, S.-C.; Wang, Y.; Huang, M.; Huang, Y.; Li, J.-Y.; Li, Y.-N.; Gao, Y.; Mao, L.; et al. Astrocyte-derived sonic hedgehog contributes to angiogenesis in brain microvascular endothelial cells via RhoA/ROCK pathway after oxygen-glucose deprivation. Mol. Neurobiol. 2013, 47, 976-987. [CrossRef] [PubMed]

133. Polizio, A.H.; Chinchilla, P.; Chen, X.; Kim, S.; Manning, D.R.; Riobo, N.A. Heterotrimeric Gi proteins link Hedgehog signaling to activation of Rho small GTPases to promote fibroblast migration. J. Biol. Chem. 2011, 286, 19589-19596. [CrossRef] [PubMed]

134. Kanda, S.; Mochizuki, Y.; Suematsu, T.; Miyata, Y.; Nomata, K.; Kanetake, H. Sonic hedgehog induces capillary morphogenesis by endothelial cells through phosphoinositide 3-kinase. J. Biol. Chem. 2003, 278, 8244-8249. [CrossRef] [PubMed]

135. Kallakuri, S.; Yu, J.A.; Li, J.; Li, Y.; Weinstein, B.M.; Nicoli, S.; Sun, Z. Endothelial cilia are essential for developmental vascular integrity in zebrafish. J. Am. Soc. Nephrol. 2015, 26, 864-875. [CrossRef] [PubMed]

136. Roncalli, J.; Renault, M.A.; Tongers, J.; Misener, S.; Thorne, T.; Kamide, C.; Jujo, K.; Tanaka, T.; Ii, M.; Klyachko, E.; et al. Sonic hedgehog-induced functional recovery after myocardial infarction is enhanced by AMD3100-mediated progenitor-cell mobilization. J. Am. Coll. Cardiol. 2011, 57, 2444-2452. [CrossRef] [PubMed]

137. Frontini, M.J.; Nong, Z.; Gros, R.; Drangova, M.; O’Neil, C.; Rahman, M.N.; Akawi, O.; Yin, H.; Ellis, C.G.; Pickering, J.G. Fibroblast growth factor 9 delivery during angiogenesis produces durable, vasoresponsive microvessels wrapped by smooth muscle cells. Nat. Biotechnol. 2011, 29, 421-427. [CrossRef] [PubMed]

138. Sicklick, J.K.; Li, Y.X.; Choi, S.S.; Qi, Y.; Chen, W.; Bustamante, M.; Huang, J.; Zdanowicz, M.; Camp, T.; Torbenson, M.S.; et al. Role for hedgehog signaling in hepatic stellate cell activation and viability. Lab. Investig. 2005, 85, 1368-1380. [CrossRef]

139. Wang, G.; Zhang, Z.; Xu, Z.; Yin, H.; Bai, L.; Ma, Z.; Decoster, M.A.; Qian, G.; Wu, G. Activation of the sonic hedgehog signaling controls human pulmonary arterial smooth muscle cell proliferation in response to hypoxia. Biochim. Biophys. Acta 2010, 1803, 1359-1367. [CrossRef]

140. Li, H.; Li, J.; Li, Y.; Singh, P.; Cao, L.; Xu, L.J.; Li, D.; Wang, Y.; Xie, Z.; Gui, Y.; et al. Sonic hedgehog promotes autophagy of vascular smooth muscle cells. Am. J. Physiol. Heart Circ. Physiol. 2012, 303, H1319-H1331. [CrossRef]

141. Morrow, D.; Sweeney, C.; Birney, Y.A.; Guha, S.; Collins, N.; Cummins, P.M.; Murphy, R.; Walls, D.; Redmond, E.M.; Cahill, P.A. Biomechanical regulation of hedgehog signaling in vascular smooth muscle cells in vitro and in vivo. Am. J. Physiol. Cell Physiol. 2007, 292, C488-C496. [CrossRef]

142. Li, F.; Duman-Scheel, M.; Yang, D.; Du, W.; Zhang, J.; Zhao, C.; Qin, L.; Xin, S. Sonic hedgehog signaling induces vascular smooth muscle cell proliferation via induction of the G1 cyclin-retinoblastoma axis. Arter. Thromb. Vasc. Biol. 2010, 30, 1787-1794. [CrossRef]

143. Doyle, A.J.; Redmond, E.M.; Gillespie, D.L.; Knight, P.A.; Cullen, J.P.; Cahill, P.A.; Morrow, D.J. Differential expression of Hedgehog/Notch and transforming growth factor-beta in human abdominal aortic aneurysms. J. Vasc. Surg. 2015, 62, 464-470. [CrossRef] [PubMed]

144. Morrow, D.; Cullen, J.P.; Liu, W.; Guha, S.; Sweeney, C.; Birney, Y.A.; Collins, N.; Walls, D.; Redmond, E.M.; Cahill, P.A. Sonic Hedgehog induces Notch target gene expression in vascular smooth muscle cells via VEGF-A. Arter. Thromb. Vasc. Biol. 2009, 29, 1112-1118. [CrossRef] [PubMed]

145. Chen, K.; Chen, Q.J.; Wang, L.J.; Liu, Z.H.; Zhang, Q.; Yang, K.; Wang, H.B.; Yan, X.X.; Zhu, Z.B.; Du, R.; et al. Increment of HFABP Level in Coronary Artery In-Stent Restenosis Segments in Diabetic and Nondiabetic Minipigs: HFABP Overexpression Promotes Multiple Pathway-Related Inflammation, Growth and Migration in Human Vascular Smooth Muscle Cells. J. Vasc. Res. 2016, 53, 27-38. [CrossRef] [PubMed] 
146. Shen, Y.; Li, C.; Zhang, R.Y.; Zhang, Q.; Shen, W.F.; Ding, F.H.; Lu, L. Association of increased serum CTRP5 levels with in-stent restenosis after coronary drug-eluting stent implantation: CTRP5 promoting inflammation, migration and proliferation in vascular smooth muscle cells. Int. J. Cardiol. 2017, 228, 129-136. [CrossRef]

147. Fitzpatrick, E.; Han, X.; Liu, W.; Corcoran, E.; Burtenshaw, D.; Morrow, D.; Helt, J.C.; Cahill, P.A.; Redmond, E.M. Alcohol Reduces Arterial Remodeling by Inhibiting Sonic Hedgehog-Stimulated Stem Cell Antigen-1 Positive Progenitor Stem Cell Expansion. Alcohol Clin. Exp. Res. 2017, 41, 2051-2065. [CrossRef]

148. Mooney, C.J.; Hakimjavadi, R.; Fitzpatrick, E.; Kennedy, E.; Walls, D.; Morrow, D.; Redmond, E.M.; Cahill, P.A. Hedgehog and Resident Vascular Stem Cell Fate. Stem Cells Int. 2015, 2015, 468428. [CrossRef]

149. Passman, J.N.; Dong, X.R.; Wu, S.P.; Maguire, C.T.; Hogan, K.A.; Bautch, V.L.; Majesky, M.W. A sonic hedgehog signaling domain in the arterial adventitia supports resident Sca1+ smooth muscle progenitor cells. Proc. Natl. Acad. Sci. USA 2008, 105, 9349-9354. [CrossRef]

150. Zhao, H.; Feng, J.; Seidel, K.; Shi, S.; Klein, O.; Sharpe, P.; Chai, Y. Secretion of shh by a neurovascular bundle niche supports mesenchymal stem cell homeostasis in the adult mouse incisor. Cell Stem Cell 2014, 14, 160-173. [CrossRef] [PubMed]

151. Zeng, Q.; Wei, B.; Zhao, Y.; Wang, X.; Fu, Q.; Liu, H.; Li, F. Shh mediates PDGF-induced contractile-to-synthetic phenotypic modulation in vascular smooth muscle cells through regulation of KLF4. Exp. Cell Res. 2016, 345, 82-92. [CrossRef] [PubMed]

152. Dohle, E.; Fuchs, S.; Kolbe, M.; Hofmann, A.; Schmidt, H.; Kirkpatrick, C.J. Comparative study assessing effects of sonic hedgehog and VEGF in a human co-culture model for bone vascularisation strategies. Eur. Cell Mater. 2011, 21, 144-156. [CrossRef] [PubMed]

153. Lee, S.W.; Moskowitz, M.A.; Sims, J.R. Sonic hedgehog inversely regulates the expression of angiopoietin-1 and angiopoietin-2 in fibroblasts. Int. J. Mol. Med. 2007, 19, 445-451. [CrossRef] [PubMed]

154. El-Hashash, A.H.; Al Alam, D.; Turcatel, G.; Rogers, O.; Li, X.; Bellusci, S.; Warburton, D. Six1 transcription factor is critical for coordination of epithelial, mesenchymal and vascular morphogenesis in the mammalian lung. Dev. Biol. 2011, 353, 242-258. [CrossRef] [PubMed]

155. El-Hashash, A.H.; Al Alam, D.; Turcatel, G.; Bellusci, S.; Warburton, D. Eyes absent 1 (Eya1) is a critical coordinator of epithelial, mesenchymal and vascular morphogenesis in the mammalian lung. Dev. Biol. 2011, 350, 112-126. [CrossRef] [PubMed]

156. Ali, H.; Emoto, N.; Yagi, K.; Vignon-Zellweger, N.; Nakayama, K.; Hatakeyama, K.; Asada, Y.; Rikitake, Y.; Hirata, K.-I. Localization and characterization of a novel secreted protein, SCUBE2, in the development and progression of atherosclerosis. Kobe J. Med. Sci. 2013, 59, E122-E131.

157. Dutzmann, J.; Koch, A.; Weisheit, S.; Sonnenschein, K.; Korte, L.; Haertle, M.; Thum, T.; Bauersachs, J.; Sedding, D.G.; Daniel, J.M. Sonic hedgehog-dependent activation of adventitial fibroblasts promotes neointima formation. Cardiovasc. Res. 2017, 113, 1653-1663. [CrossRef]

158. Herring, B.P.; Hoggatt, A.M.; Griffith, S.L.; McClintick, J.N.; Gallagher, P.J. Inflammation and vascular smooth muscle cell dedifferentiation following carotid artery ligation. Physiol. Genom. 2017, 49, 115-126. [CrossRef]

159. Teng, H.; Chopp, M.; Hozeska-Solgot, A.; Shen, L.; Lu, M.; Tang, C.; Zhang, Z.G. Tissue plasminogen activator and plasminogen activator inhibitor 1 contribute to sonic hedgehog-induced in vitro cerebral angiogenesis. PLoS ONE 2012, 7, e33444. [CrossRef]

160. Maun, H.R.; Wen, X.; Lingel, A.; de Sauvage, F.J.; Lazarus, R.A.; Scales, S.J.; Hymowitz, S.G. Hedgehog pathway antagonist 5E1 binds hedgehog at the pseudo-active site. J. Biol. Chem. 2010, 285, 26570-26580. [CrossRef]

161. Vanlandewijck, M.; He, L.; Mae, M.A.; Andrae, J.; Ando, K.; Del Gaudio, F.; Nahar, K.; Lebouvier, T.; Lavina, B.; Gouveia, L.; et al. A molecular atlas of cell types and zonation in the brain vasculature. Nature 2018, 554, 475-480. [CrossRef] [PubMed]

(C) 2019 by the authors. Licensee MDPI, Basel, Switzerland. This article is an open access article distributed under the terms and conditions of the Creative Commons Attribution (CC BY) license (http://creativecommons.org/licenses/by/4.0/). 